\title{
King crabs up-close: ontogenetic changes in ornamentation in the family Lithodidae (Crustacea, Decapoda, Anomura), with a focus on the genus Paralomis
}

\author{
Sally HALL \\ Sven THATJE \\ National Oceanography Centre, Southampton (NOCS), \\ School of Ocean and Earth Science, University of Southampton, \\ European Way, Southampton, SO14 3ZH (UK) \\ smh57@noc.soton.ac.uk
}

KEY WORDS
Crustacea,
Decapoda,
Lithodidae,
Paralomis,
tubercle,
spine,
ontogeny.

Hall S. \& Thatje S. 2010. - King crabs up-close: ontogenetic changes in ornamentation in the family Lithodidae (Crustacea, Decapoda, Anomura), with a focus on the genus Paralomis. Zoosystema 32 (3): 495-524.

\begin{abstract}
In this study, we describe the carapace ornamentation found in species of Lithodidae (Decapoda, Anomura), focussing primarily on the genus Paralomis, which displays the greatest diversity of forms, globally. Evidence of ontogenetic change in the surface ornamentation of lithodids has previously been highlighted for one species of Paralomis (P. granulosa Jaquinot, 1847); however, its wider occurrence within the family has never been formally examined. Growth-related change in dorsal spines and tubercles was considered using growth-series from eight species of Paralomis (P. mendagnai, S Pacific; P. multispina, N Pacific; P. spinosissima, P. granulosa, S Atlantic; P. inca, SE Pacific; P. erinacea, E Atlantic; P. cubensis, Caribbean; $P$. stella, $S$ Indian Ocean). Tubercular structures from adult specimens of 24 additional species of Paralomis are figured in order to provide a reference for future diagnosis. This study shows that ontogenetic changes should be considered when identifying specimens of Lithodidae to species level.
\end{abstract}

\section{RÉSUMÉ}

Gros plan sur les crabes royaux: changements ontogénétiques de l'ornementation dans la famille Lithodidae (Crustacea, Decapoda, Anomura), le cas du genre Paralomis.

Dans cet article, nous examinons et décrivons l'ornementation de carapace trouvée chez des espèces de Lithodidae (Decapoda, Anomura), en nous concentrant principalement sur le genre Paralomis, qui présente la plus grande diversité de formes. Le changement ontogénétique de l'ornementation de surface des Lithodidae a été précédemment mise en évidence chez une espèce de Paralomis (P. granulosa Jaquinot, 1847), toutefois son occurrence plus large dans la famille n’a jamais 


\author{
MOTS CLÉS \\ Crustacea, \\ Decapoda, \\ Lithodidae, \\ Paralomis, \\ tubercule, \\ épines, \\ ontogénèse.
}

été formellement examinée. Le changement des épines et des tubercules dorsaux durant la croissance a été étudié à l'aide de séries de croissance de huit espèces de Paralomis (P. mendagnai, Pacifique S; P. multispina, Pacifique N; P. spinosissima et $P$. granulosa, Atlantique $S$; $P$. inca, Pacifique SE; $P$. erinacea, Atlantique E; $P$. cubensis, Caraïbe; $P$. stella, Océan Indien S). Des structures tuberculeuses des spécimens adultes de 24 espèces additionnelles de Paralomis sont figurées afin de fournir une référence pour les diagnoses futures. Cette étude montre que des changements ontogénétiques devraient être pris en considération pour l'identification des spécimens de Lithodidae au niveau de l'espèce.

\section{INTRODUCTION}

King crabs of the family Lithodidae Samouelle, 1819 , inhabit cold waters, predominantly in the deep sea, and are represented by species in most of the world's oceans. The deep water, patchy distribution (63\% of species never found shallower than $200 \mathrm{~m}$, $39 \%$ never found shallower than $500 \mathrm{~m}$ ) (Hall \& Thatje 2009a) means that many species of king crab are not commonly or easily targeted for sampling. Many species are based on a description of one or two specimens, and are recovered infrequently after first publication (Macpherson 1988a; Spiridonov et al. 2006; Hall \& Thatje 2009b). Some of the characters used to distinguish species of king crab are the size, position and form of dorsal carapace ornamentation (Macpherson 1988a). The 100+ described lithodid species and particularly the 61 extant species of the genus Paralomis White, 1856 (Zaklan 2002; Macpherson 2003; Spiridonov et al. 2006; Takeda \& Bussarawit 2007; Macpherson \& Chan 2008; Hall \& Thatje 2009b) display an array of spines and tubercles, with or without setae, which can aid diagnosis. Few authors have given images of these structures under magnification, but those that have (e.g., Haig 1974; Andrade 1980) have revealed the intricate structures that adorn carapaces within this family.

\section{TERMINOLOGY}

In scientific writing on the Lithodidae, the words used to describe carapace structures are various and sometimes poorly defined. The word "tubercle"
(Haig 1974; Macpherson 1988a) describes small protuberances, swellings or nodules, and is often used interchangeably with the terms "papillae" (Faxon 1895; Haig 1974), "granule" (Macpherson 1988a, 1992), "flattened spinules" (Takeda 1974) and "vesiculous granules" (Takeda \& Ohta 1979). These terms actually describe a whole spectrum of morphological features (Appendix 1), but in an inconsistent way that can sometimes be unhelpful in diagnosis. If described in an unambiguous manner through the provision of detailed drawing or photography, real differences could be used to identify species more accurately; to delimit lineages; and to allow non-specialists to make useful comparisons between the works of different authors.

\section{ONTOGENY}

The difference in expression of carapace ornamentation within a species at successive stages of growth has been noted by several authors (Haig 1974; Takeda 1974; Ingle \& Garrod 1987; Macpherson 1988a-c, 1990; Macpherson \& Chan 2008). “The clear difference between juvenile and adult lithodids has been pointed out, and illustration is strongly recommended" (Macpherson \& Chan 2008). This phenomenon occurs in other decapod families, such as in Cancer pagurus Linnaeus, 1758, which displays progressively fewer features on its carapace in successive moults, from crab stage 1 to adults (Ingle 1981). Particularly in members of the lithodid genus Neolithodes A. Milne-Edwards \& Bouvier, 1894 , variation in spine length and density between juveniles and adults makes identification to species 
level problematic - especially when a whole growth series isn't available for comparison. In descriptions of several species of the genus Neolithodes, the ontogenetic change itself is mentioned as a characteristic for identification (e.g., N. agassizii Smith, 1882, N. diomedeae Benedict, 1894, N. asperrimus Barnard, 1947: in Macpherson 1988a). Within many species of lithodid, it seems that major spines vary in size but not relative position on the carapace (Macpherson \& Chan 2008). Differing growth stages can usually be unified as a single species using features other than the spines and tubercles; however, the microscopic changes can often have substantial effects on the macroscopic appearance of a specimen. The identification process would be enhanced by increasing the available knowledge in this area.

\section{ENVIRONMENTAL EFFECTS}

In addition to changes between ontogenetic stages, changes within a moult stage caused by the erosion of spines, breakage and re-growth, or fouling of the surface, can hinder identification. The state of fouling on the carapace can assist in determining the age of a moult stage, and this should be considered. Whereas juvenile and young reproductive adult stages have annual or semi-annual moult cycles, it is estimated that there can be several years between moulting stages of larger adults (McCaughran \& Powell 1977). The effect of environmental attrition can therefore be assumed to be greater in larger adults.

A taxonomist attempting to identify a potentially novel species is unlikely to have a complete growth series of similar species available to refer to. Here, we aim to look for common ontogenetic trajectories within the Lithodidae and to provide the basis of a catalogue covering intraspecific variety.

\section{MATERIALS AND METHODS}

Specimens were obtained from museum collections or from un-deposited cruise materials (Mauritania: MAU 1107; fisheries projects, Southern Ocean). Specimens were identified to species-level using features such as the shape of the carapace; the form of the legs, chelae, abdomen, and rostrum; and the position of spines

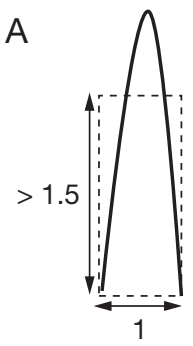

B
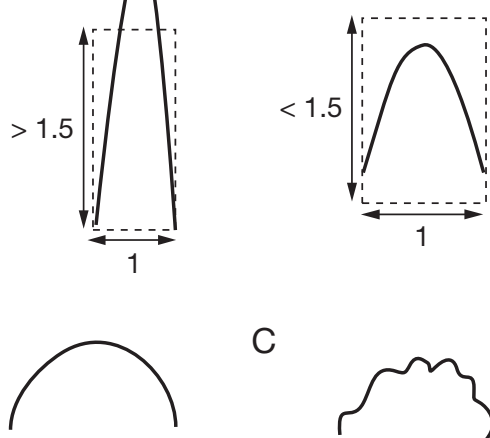

C
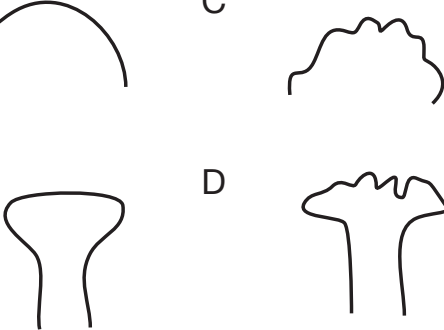

D

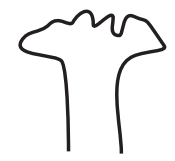

$E$
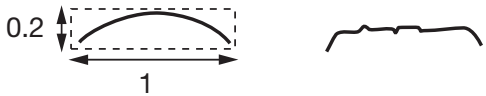

FIG. 1. - Terminology for describing carapace ornamentation in species of Paralomis White, 1856: spines (A) are structures which measure more than 1.5 times as high as wide at the base; tubercles (B-E) are any structures measuring less than 1.5 times high as wide at the base; within this system, tubercles can be conical (B), rounded (C), pedunculate (D) or flattened (E), and have regular (smooth) or irregular surfaces. Conical tubercles differ from rounded tubercles in that they taper towards an acute apex. Flattened tubercles are lower than 0.2 times as high as wide at the base. Numbers represent ratios.

on the lateral margin of the carapace. In this study, the terminology used to describe ornamentation of Paralomis (Fig. 1) was: "tubercle", which replaced previously used synonyms: granule and papilla to describe structures that are not spines; and "spine", which describes structures measuring more than 1.5 times as high as they are wide at the base. A distinction was then made between conical, flattened, pedunculate or rounded tubercles, and regular or irregular tubercles. Elsewhere, terminology follows Macpherson (1988a), and measurements of carapace length $(\mathrm{CL})$ are taken from the base of the orbit to the posterior edge, excluding lateral spines.

For 32 species of Paralomis, adult specimens (larger than CL $50 \mathrm{~mm}$ ) were illustrated under 
magnification (Figs 2-15; Appendix 1) in order to provide a reference for future descriptive works. Eight species of Paralomis with good representation in sample collections were also selected to illustrate the growth-related changes within the genus (P. cubensis Chace, 1939; P. erinacea Macpherson, 1988; P. granulosa Jaquinot, 1847; P. inca Haig, 1974; P. mendagnai Macpherson, 2003; P. multispina Benedict, 1894; P. spinosissima Birstein \& Vinogradov, 1972; P. stella Macpherson, 2001). These sample species were also chosen to cover a range of habitat depths and localities and so to reflect the global distribution of the genus.

Following the Ingle \& Garrod (1987) study on Paralomis granulosa, from the Falkland Islands, specimens from three size classes (determined by carapace length from orbital to posterior margin, excluding lateral spines) $10-25 \mathrm{~mm}, 30-50 \mathrm{~mm}$, $50+\mathrm{mm}$ were examined; and up to three were chosen for illustration where differences were evident. In all Paralomis species figured (except possibly $P$. inca), the 30-50 $\mathrm{mm}$ and the 50+ size classes typically contain reproductively mature females (Lovrich \& Vinuesa 1993; S. Hall pers. obs.). Maximum sizes for species range between 60 and $110 \mathrm{~mm}$ (Macpherson 1988a; Zaklan 2002; S. Hall pers. obs.). No juvenile specimens of Paralomis erinacea are deposited in museums; however, the change in form between adults in the studied range warrants their inclusion in the growth series. Figured specimens were judged to be representative of their size class by microscopic and macroscopic comparison. Actual sample measurements are stated in the relevant sections, and there was no observed difference in the features studied correlated with a division between the sexes. Growth-series specimens were obtained from as close to the type locality as possible.

The dorsal carapace, abdomen, and legs of each specimen were examined under a light microscope to assess the consistency of tubercle form within one specimen. Where a difference is observed, it is noted in the results. The figured region is a dorsal view, depicting the mid point of the right branchial region, unless otherwise stated in the figure legend. Pictures are taken using the "macro" setting of a Sony 8.2 megapixel digital camera attached to the lens of an optical microscope.

\section{ABBREVIATIONS}

BMNH The Natural History Museum, London;

MNHN Muséum national d'Histoire naturelle, Paris; USNM National Museum of Natural History, Smithsonian Institution, Washington, DC.

\section{RESULTS}

Photographs and drawings were taken of the midbranchial region of the dorsal carapace, and were, on the whole, representative of the entire dorsal carapace (exceptions are noted in the text). Spination of the lateral margins is usually independent in form to that found elsewhere on the carapace, and tends to vary only in relative size between life stages (S. Hall, pers. obs.).

Images of 24 additional species of the genus Paralomis (Figs 10-15; Appendix 1) demonstrate the diversity of ornamentation within adults (and in two cases, of juveniles) of the Lithodidae, with a view to standardising terminology and aiding future identifications using carapace features.

\section{Paralomis cubensis Chace, 1939}

(Fig. 2)

Paralomis cubensis Chace, 1939: 49. - Macpherson 1988a: 97, fig. 44, pl. 22B, 23A.

TYPE LOCALITY. - East of Havana, Cuba, $23^{\circ} 12^{\prime} 30^{\prime \prime} \mathrm{N}$, $82^{\circ} 12^{\prime} \mathrm{W}, 420-548 \mathrm{~m}$.

Distribution. - Caribbean Sea and Western Atlantic, $1-27^{\circ} \mathrm{N}, 300-600 \mathrm{~m}$.

MATERIAl EXAMined. $-5 \% \circ$ (CL 25-52 mm), $130^{7} 0^{7}$ (CL 23-85 mm) (including paratypes).

Specimens figured. - RV Miss Virginia, 329-366 m, 21.III.1962, 1 ㅇ CL 26 mm (USNM-231310). $26^{\circ} 45^{\prime} \mathrm{N}, 84^{\circ} 55^{\prime} \mathrm{W}, 466-732 \mathrm{~m}, \mathrm{XII} .1983,1$ ㅇ CL $45.8 \mathrm{~mm}$ (USNM-213542). - Amazon River Mouth, $411 \mathrm{~m}$, XI.1957, 1 ㅇ CL 79.6 mm (USNM-231312).

\section{REMARKS}

In the original description of the $53.2 \mathrm{~mm}$ female holotype of Paralomis cubensis, Chace (1939) notes "the dorsal carapace crowded with tubercles of different sizes, low and rounded on most surfaces, becoming more acute towards the margins". This description 

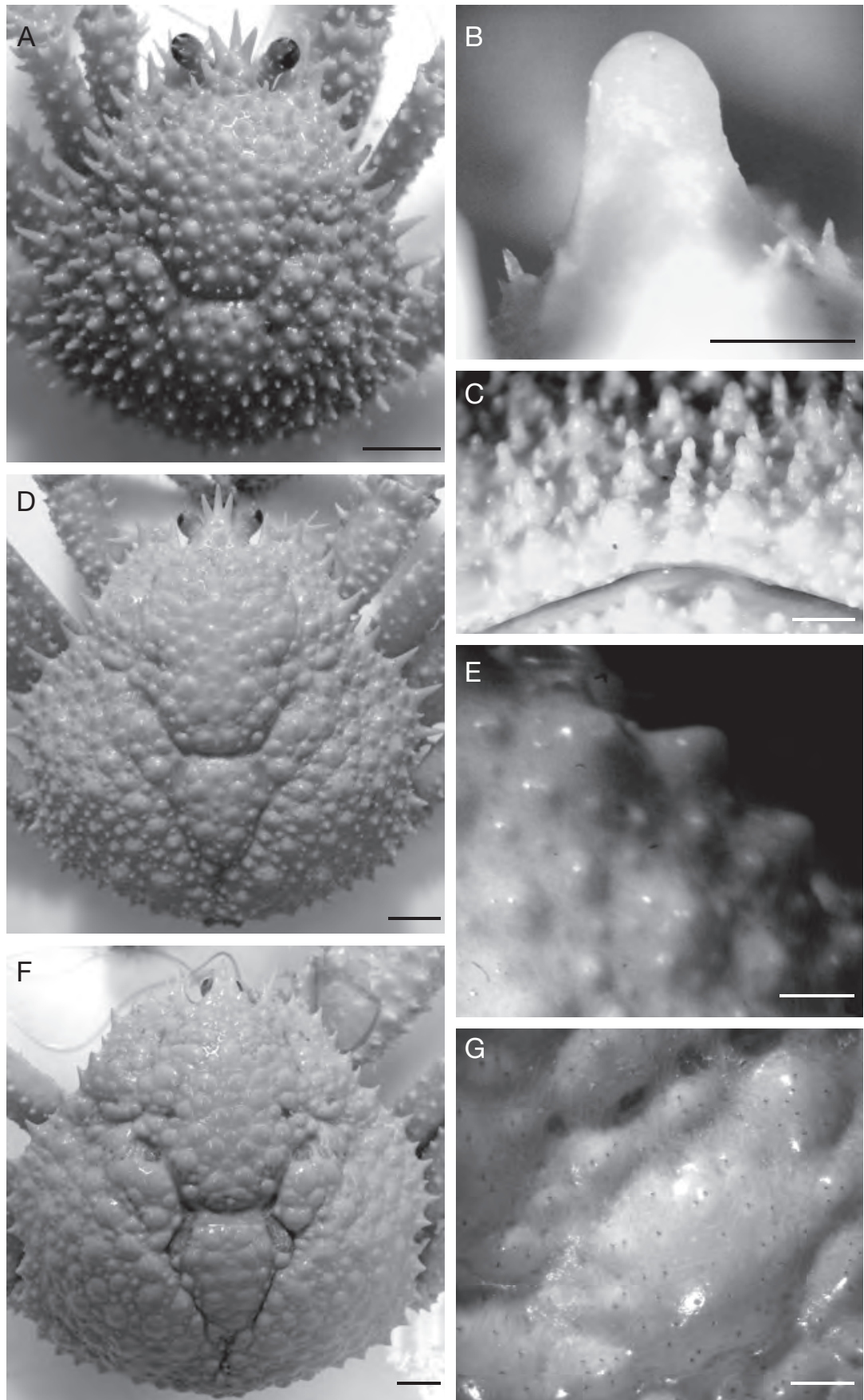

FIG. 2. - Paralomis cubensis Chace, 1939: A-C, CL 26 mm (USNM-231310), RV Miss Virginia, 329-366 m, 21.III.1962; D, E, ㅇ

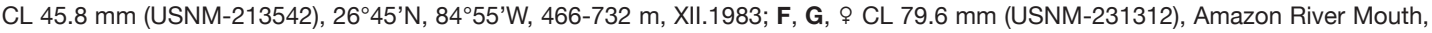
$411 \mathrm{~m}, \mathrm{XI} .1957$; A, carapace, dorsal view; B, mid-branchial spine, posterio-lateral view; C, mid-branchial spines, posterio-lateral view; D, carapace, dorsal view; E, mid-branchial region, dorsal view; F, carapace, dorsal view; G, mid-branchial region, dorsal view. Scale bars: A, D, $5 \mathrm{~mm}$; B, $1 \mathrm{~mm}$; C, 2 mm; E, G, 4 mm; F, $10 \mathrm{~mm}$. 
matches the figured specimen (Fig. 2D, E) in the CL 30-50 mm size class. Substantial ontogenetic change is seen in P. cubensis, with later growth stages bearing progressively flattened tubercles (Fig. 2G). Specimens smaller than CL $30 \mathrm{~mm}$ bore pedunculate tubercles or spines with a bulbous swelling at the apex (Fig. 2B, C). Setae are not found on the apices of these tubercles at any growth stage, instead tubercles are covered evenly in short setae. Macpherson (1988a) reports corroborating features in a CL $28 \mathrm{~mm}$ specimen, "granules very acute, forming small spines" but does not include a figure.

\section{Paralomis erinacea Macpherson, 1988} (Fig. 3)

Paralomis erinacea Macpherson, 1988a: 82, figs 36A, 37, pl. 19A.

TYPE LOCALITY. - Syntypes taken from Guinea Bissau and the Ivory Coast 251-900 m.

DisTRIBUTION. - East coast of Africa, from Mauritania to the Ivory Coast, 251-1500 m.

MATERIAL EXAMINED. — 9 우 (CL 44-66 mm); 8 o $^{7} 0^{\prime \prime}$ (CL 61-83 mm).

SPECIMENS Figured. - Guinea Bissau, 1 ㅇ CL $44.87 \mathrm{~mm}$ (MNHN Pg-2937). — Mauritania 14.XII.2007, 1 @ CL $59 \mathrm{~mm}, 1$ CL $83 \mathrm{~mm}$ (both specimens in collection of A. Ramos, Vigo, Spain).

\section{REMARKS}

In the original description of this species (Macpherson 1988a), 9 adult specimens were examined, CL 46-78 mm. Our examination slightly extends this range, doubling the specimen count, and examining newly identified individuals from CL $44 \mathrm{~mm}$ to $83 \mathrm{~mm}$. Macpherson (1988a: fig. 37G) shows spines similar to those that we found on the smaller size classes (40-50 mm, Fig. 3B). These are large conical spines, of uniform size, bearing small setae. The larger specimen, at CL $83 \mathrm{~mm}$ (Fig. 3E, F) has spines which are wider, lower and blunter than those originally figured specimens.

The macroscopic appearance of the larger adults is smoother than that of the spiny smaller adults, and might be a cause of misidentification. In P. erinacea, the lateral spines are similar in form to the dorsal spines.

\section{Paralomis granulosa (Jaquinot, 1847)}

(Fig. 4)

Lithodes granulosa Jaquinot, 1847: figs 15-21, plate 8.

Lithodes granulosus - White 1847: 56.

Lithodes granulata Jaquinot, 1853: 94.

Lithodes verrucosa Dana, 1852: 428; 1855: pl. 26, fig. 16. - Cunningham 1871: 494.

Paralomis verrucosa Bouvier, 1895: 187, pl. 13, fig. 3. Bouvier 1896: 26.

Paralomis granulosa White, 1856: 134.

Distribution. - Patagonia and the Falkland islands, $5-130 \mathrm{~m}$.

Material eXAmineD. -20 우 (CL 28-55 mm), 17 o o o (CL 13-90 mm).

Specimens figured. - Strait of Le Maire, Tierra del Fuego, 25.IV.1971, 1 o CL 25.6 mm (USNM231429). - Tierra del Fuego, $10 \mathrm{~m}, 1$ ○ CL $45.6 \mathrm{~mm}$,

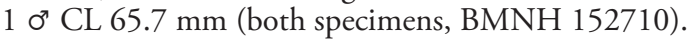

\section{Remarks}

Paralomis granulosa, studied by Ingle \& Garrod (1987), demonstrates the ontogenetic progression of tubercular flattening observed in P. cubensis. Small specimens (particularly those CL $10-25 \mathrm{~mm}$ ) are covered with very distinctive pedunculated irregular tubercles (Fig. 4A, B), sometimes described as "boleate" (Ingle \& Garrod 1987). These progressively become less pedunculated (Fig. 4D) until they are reduced to low tubercles (Fig. 4F). This reduction does not happen evenly across the carapace, with the more lateral tubercles tending to flatten first. The largest specimen that we found bearing pedunculated tubercles was CL $35 \mathrm{~mm}$. In very large specimens of up to CL $90 \mathrm{~mm}$ (not mentioned in the 1987 work on this species), the tubercular cover can be quite sparse, and fouling or wear on the carapace can be substantial, as moults become less frequent (McCaughran \& Powell 1977). The 1987 study of Falkland Island populations, conducted by Ingle \& Garrod, is supported by our results, and can be generalised over the wider geographic range of the species. 

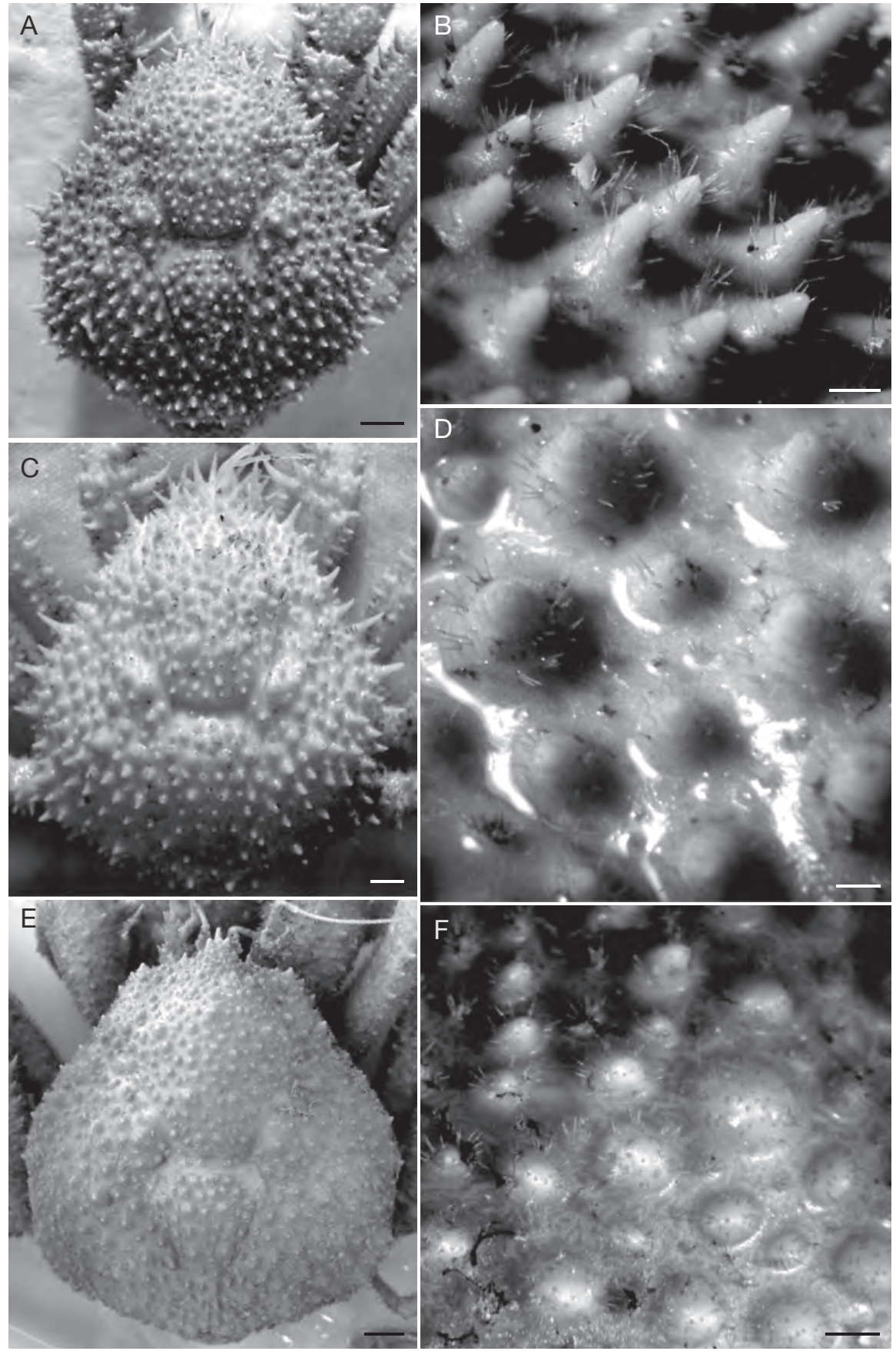

FIG. 3. - Paralomis erinacea Macpherson, 1988: A, B, \& CL 44.87 mm (MNHN Pg-2937); C, D, \& CL 59 mm (specimen in collection of Dr Ramos, Vigo), Mauritania, 14.XII.2007; E, F, o CL 83 mm (specimen in collection of Dr Ramos, Vigo), Mauritania, 14.XII.2007; A, carapace, dorsal view; B, dorsal spines, posterior view; C, carapace, dorsal view; D, dorsal spines, posterior view; E, carapace, dorsal view; F, dorsal tubercles, posterior view. Scale bars: A, C, $5 \mathrm{~mm}$; B, F, 2 mm; D, $1 \mathrm{~mm}$; E, $10 \mathrm{~mm}$. 

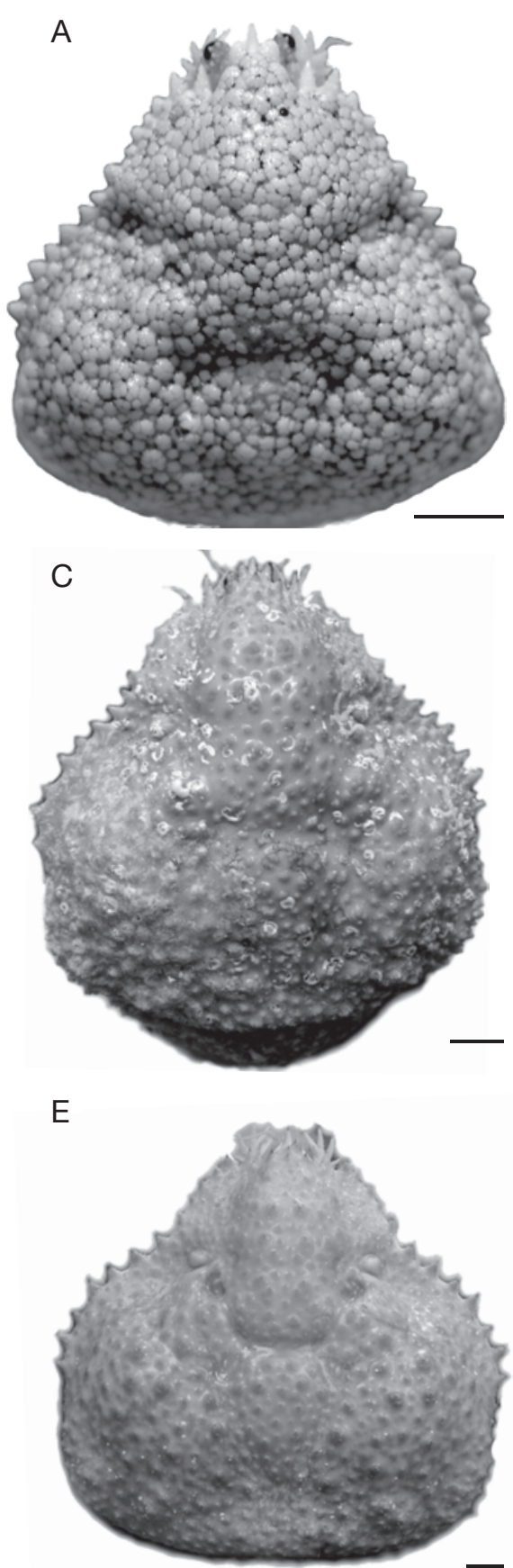
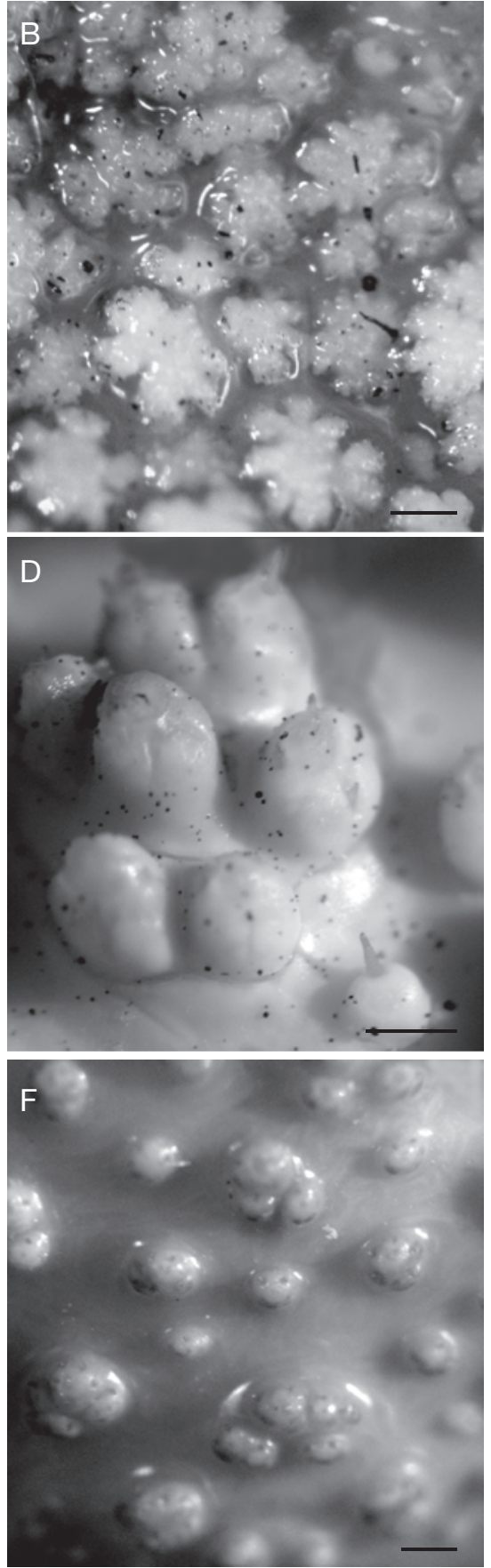

FIG. 4. - Paralomis granulosa Jaquinot, 1852: A, B, ơ CL 25.6 mm (USNM-231429), Strait of Le Maire, Tierra del Fuego, 25.IV.1971; C, D, + CL 45.6 mm (BMNH-152710); E, F, ơ CL 65.7 mm (BMNH-152710), Tierra del Fuego, 1939; A, carapace, dorsal view; B, mid-branchial region pedunculated tubercles, dorsal view; C, carapace, dorsal view; D, mid-branchial tubercle, postero-lateral view; E, carapace, dorsal view; F, mid-branchial region, dorsal view. Scale bars: A, C, E, 5 mm; B, D, F, 1 mm. 

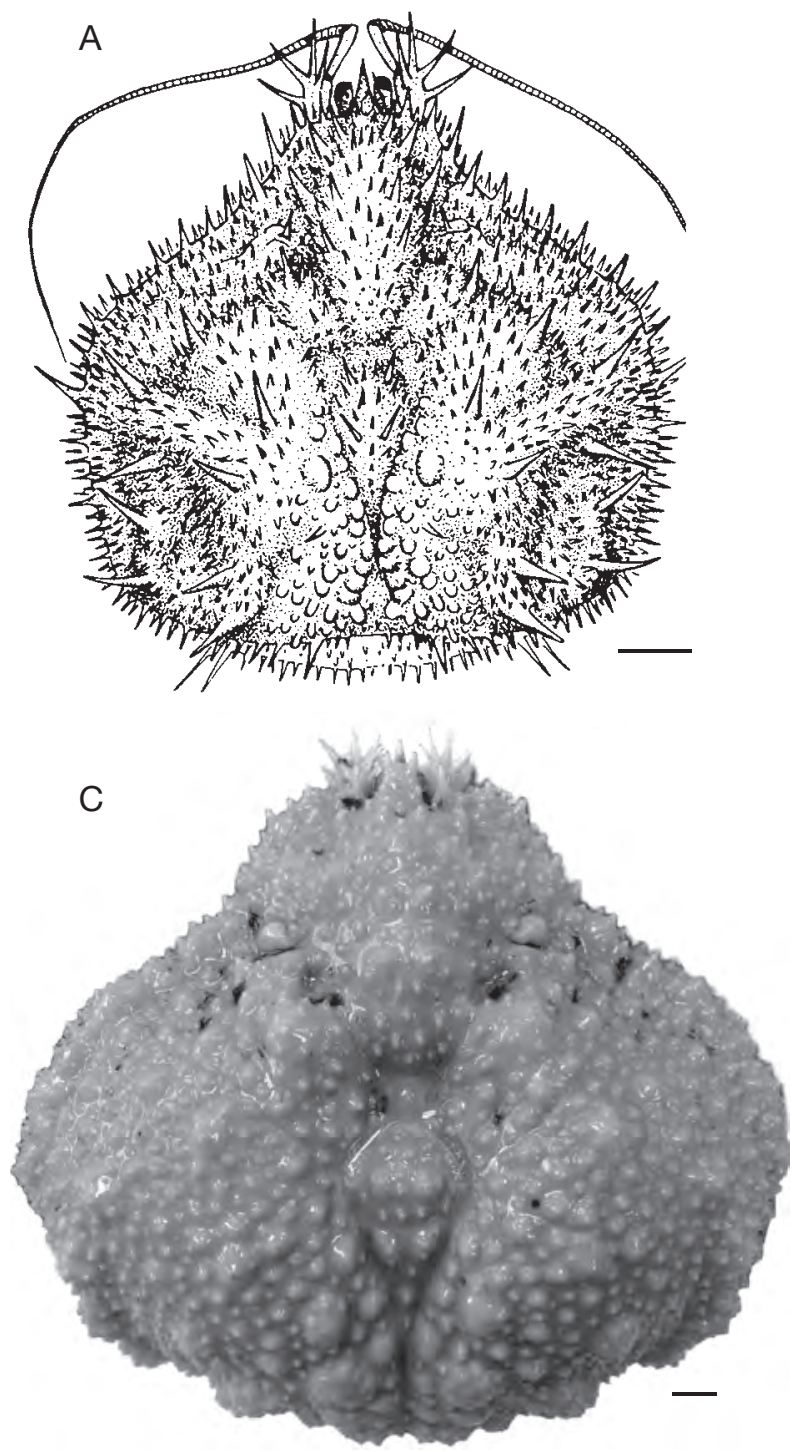
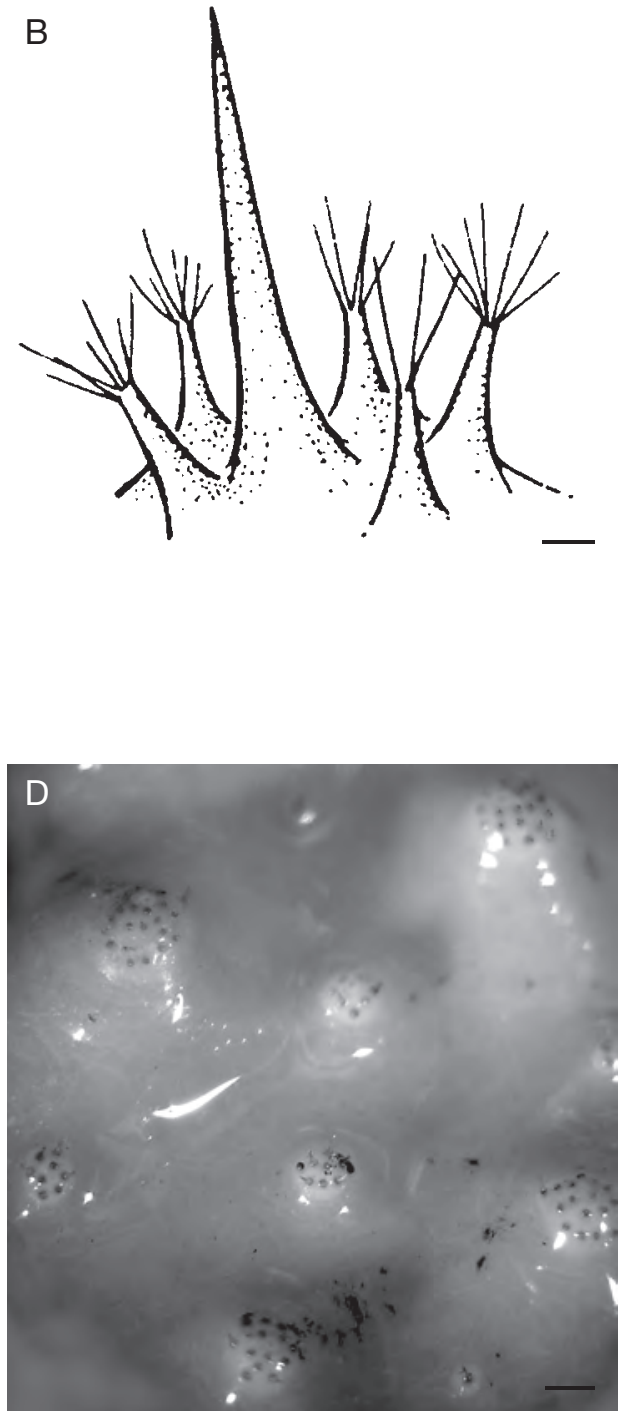

FIG. 5. - Paralomis inca Haig, 1974: A, B, ơ CL 69 mm (image of paratype from Haig 1974), 12 miles SW of Banco de Mancora, Peru, 620 m, III.1971; C, D, ᄋ CL 96 mm (USNM-259223), 749’00”S, 80³8’00”W, 705-735 m; A, carapace, dorsal view; B, carapace spine, lateral view; C, carapace, dorsal view; D, mid-branchial tubercle, lateral view. Scale bars: A, C, 10 mm; B, D, 1 mm.

Paralomis inca Haig, 1974 (Fig. 5)

Paralomis inca Haig, 1974: 157, figs 3, 4.

TyPe LOCAliTY. - Pacific coast of Ecuador and Peru, $06^{\circ} 31.5^{\prime} \mathrm{S}, 81^{\circ} 01.5^{\prime} \mathrm{W}, 600-800 \mathrm{~m}$.

MATERIAL EXAMINED. -6 $\%$ $(\mathrm{CL}>90 \mathrm{~mm})$. Informa- tion about smaller size classes comes from the original description (Haig 1974).

SPECIMEN FigURED. - 749'00"S, 80³8'00”W, 705735 m, 1 CL 96 mm (USNM-259223).

REMARKS

No specimen of Paralomis inca (Fig. 5) examined 
by us was smaller than CL $90 \mathrm{~mm}$, and the smallest of the "adult" type collection (Haig 1974) was CL $80 \mathrm{~mm}$. In the original description (Haig 1974: fig. 4), a figure of a juvenile (CL $69 \mathrm{~mm}$ ) is double the normal minimum size of maturity for many species of the genus (Zaklan 2002). Haig (1974) does indicate a marked difference between juvenile and adult spines (Fig. 5). In large specimens, tubercles are low, regular mounds, with a circular patch of short setae at the apex. In the small paratype, the dorsal ornamentation is much more spiniform, with long setae emanating from the apex.

Paralomis mendagnai Macpherson, 2003 (Fig. 6)

Paralomis mendagnai Macpherson, 2003: 414, figs 1-3.

TYPE LOCALITY. — Solomon Islands, $9^{\circ} 06.9^{\prime}$ S, $159^{\circ} 53.2^{\prime} \mathrm{E}$, 869-912 m

Distribution. - Solomon Islands, 400-1200 m.

Material eXamined. -6 \% 9 (CL 7-49.9 mm), $60^{\circ} 0^{\circ}$ (CL 11-59 mm).

SPECIMENS FIGURED. - Solomon Islands, $896-1012 \mathrm{~m}$, 25-26.IX.2001, 3 ơ ơ CL 11, 36, 58.8 mm (MNHN Pg-6408).

\section{REMARKS}

From an ovigerous female found $700-800 \mathrm{~m}$ in the Solomon Islands, this species is known to be reproductively mature by at least CL $50 \mathrm{~mm}$. Paralomis mendagnai appears to be different from other South Pacific groups studied (Fig. 14) in the smoothly rounded tubercles of the adults, which have pits (possibly minute setae) on the apex (not in a circular pattern). Specimens in the CL 10-25 mm size class had conical, or spiniform tubercles, unlike anything found on specimens above CL $30 \mathrm{~mm}$. The small paratype of $P$. mendagnai, (Fig. 6A, B) has a spiniform enlargement (Fig. 6B) of one of the conical tubercles of the mid-branchial region, whereas the surrounding tubercles are much smaller. In positions on the carapace where juveniles have such enlarged conical tubercles, specimens larger than CL $30 \mathrm{~mm}$ have only wide (> $3 \mathrm{~mm}$ diameter), flat or rounded tubercles (Fig. 4D, F).

\section{Paralomis multispina (Benedict, 1894)}

(Fig. 7)

Leptolithodes multispina Benedict, 1894: 484. — Rathbun 1904: 165.

Paralomis multispina - Schmitt 1921: 159, pl. 23; pl. 30, figs 7, 8. — Makarov 1938: 257, fig. 102. — Sakai 1971: pl. 6, fig. 2; pl. 14, figs 1, 2.

Distribution. - North Pacific, particularly around Japan, approximately 500-1100 m.

Material eXAMined. -7 우 (CL 14-93 mm); 9 o $0^{7}$ (CL 7-105 mm).

Specimens Figured. - Sea Lion rocks, WA, $1253 \mathrm{~m}$, 1 CL 17 mm (USNM-18591). - San Diego, CA, 1503 m, 1 CL 68 mm (USNM-18589).

\section{REMARKS}

In P. multispina, the spines in the larger size classes (CL > $50 \mathrm{~mm}$ ) are stout, sharp-tipped, and conical, flattened at an oblique (posterior facing) angle, and with a circumference of short setae around that face (Fig. 7E). Juveniles (CL 7-30 mm) of P. multispina have short, blunt, pedunculated tubercles, bearing a halo of short setae (Fig. 7B, C). In specimens of around CL $30 \mathrm{~mm}$, there is evidence for the tubercles becoming longer and developing an acute tip, as in larger adults. In all specimens, one spine in the mid-gastric region is larger than the other spines or tubercles, and which has no setae, nor does it have a flattened region posteriorly: this spine appears to be particularly large in relation to the lower tubercles on small specimens.

\section{Paralomis spinosissima \\ Birstein \& Vinogradov, 1972}

(Fig. 8)

Paralomis spinosissima Birstein \& Vinogradov, 1972: 352, figs $1,2$.

Type locality. - Off South Georgia, 640-650 m, $53^{\circ} 37^{\prime} \mathrm{S}, 36^{\circ} 13^{\prime} \mathrm{W}$.

DisTribution. - South Georgia and the southern and western coasts of Cape Horn, 150-800 m. 

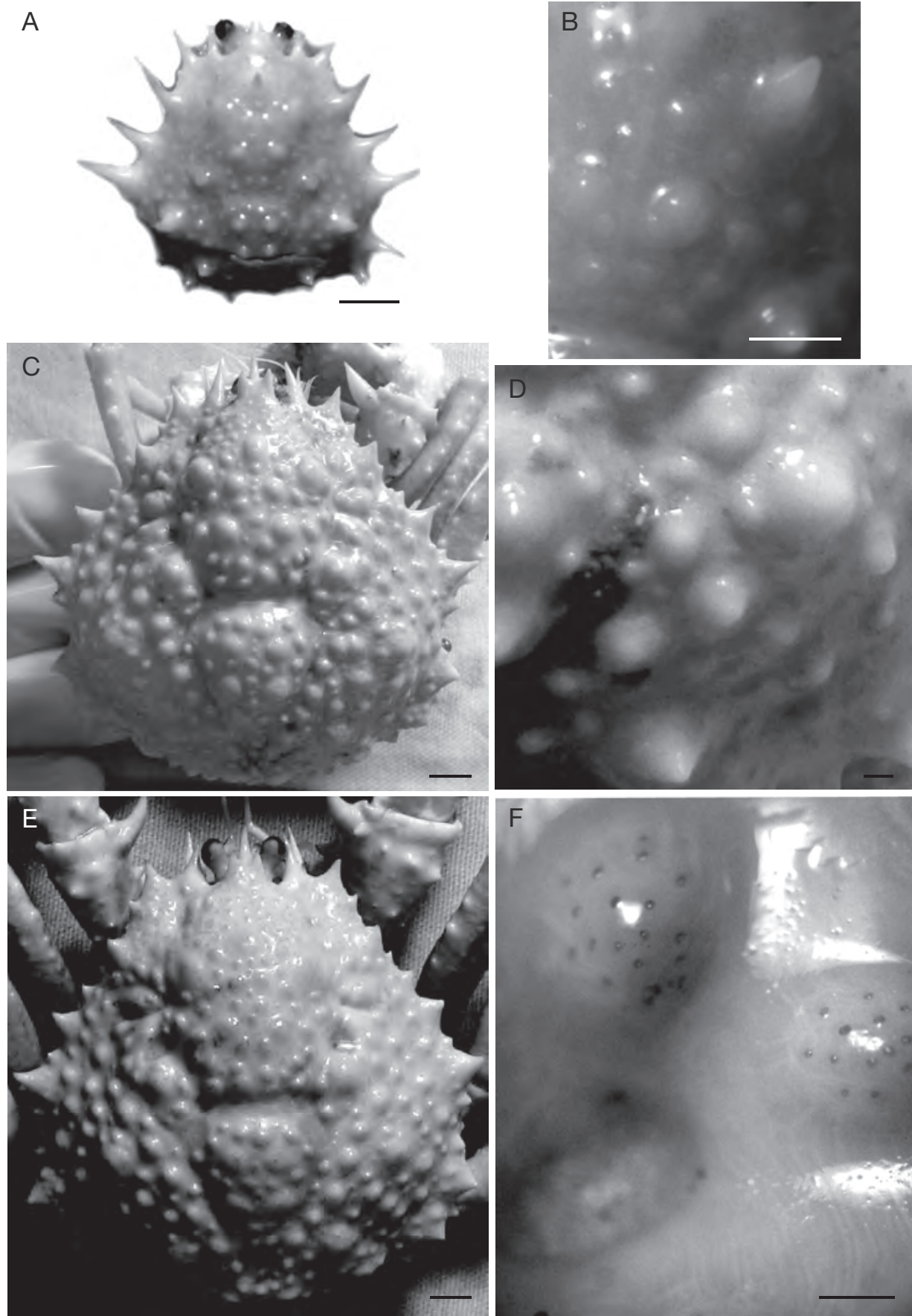

FIG. 6. - Paralomis mendagnai Macpherson, 2003: A, B, ơ CL 11 mm (MNHN Pg-6408), Solomon Islands, 1001-1012 m, 26.IX.2001, SALOMON 1, stn CP 1753; C, D, ơ CL 36 mm (MNHN Pg-6408), Solomon Islands, 896-912 m, 25.IX.2001, SALOMON 1, stn CP 1752; E, F, holotype o' 58.8 mm (MNHN Pg-6408), Solomon Islands, 896-912 m, 25.IX.2001, SALOMON 1, stn CP 1752; A, carapace, dorsal view; B, mid-branchial region, dorsal view; C, carapace, dorsal view; D, mid-branchial region, dorsal view; E, carapace, dorsal view; F, mid-branchial flattened tubercle. Scale bars: A, C, E, $5 \mathrm{~mm} ; \mathrm{B}, \mathrm{D}, \mathrm{F}, 1 \mathrm{~mm}$. 

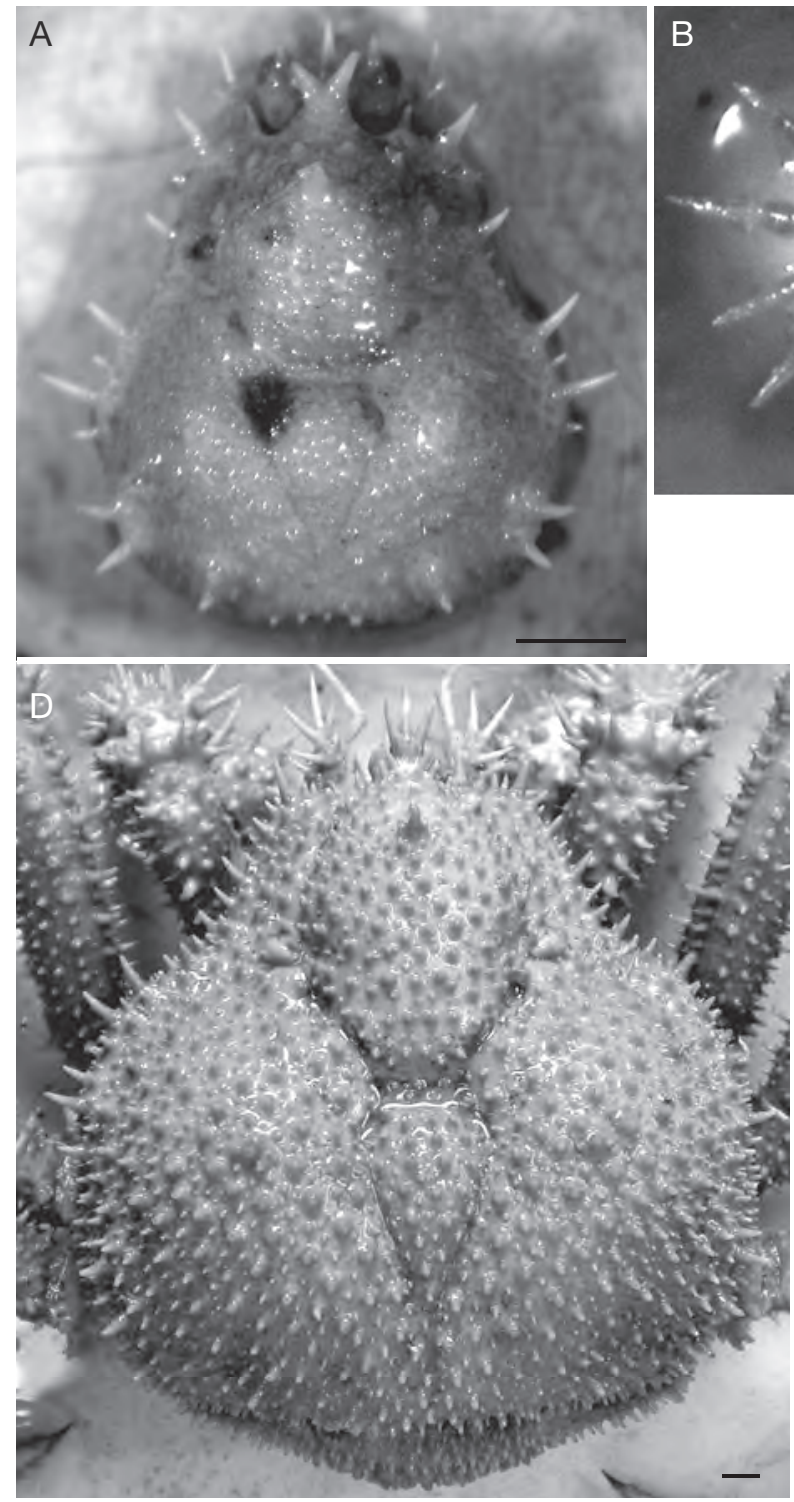
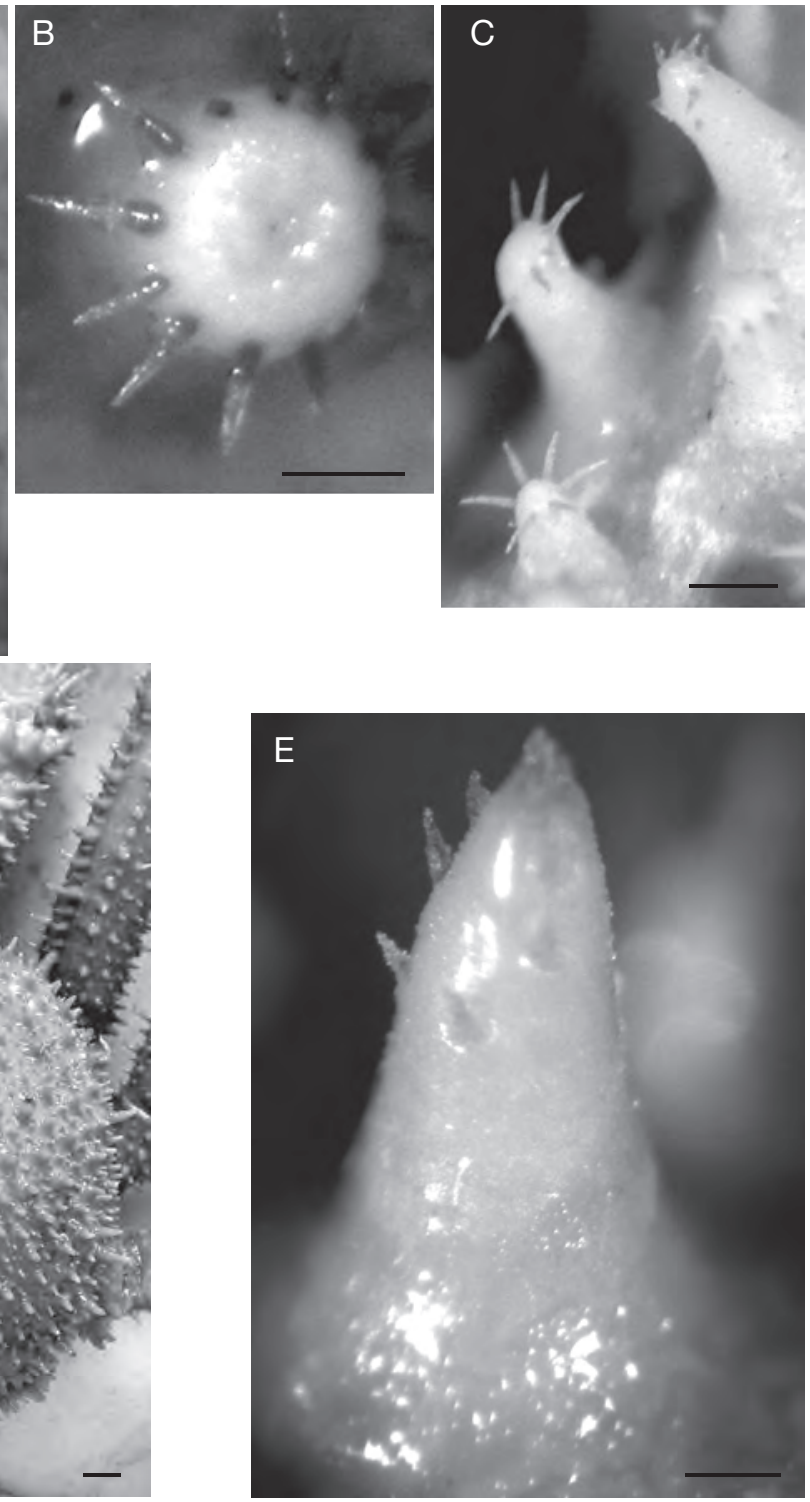

FIG. 7. - Paralomis multispina Benedict, 1895: A-C, o CL 17 mm (USNM-18591), Sea Lion rocks, WA, 1253 m; D, E, o CL 68 mm (USNM-18589); A, carapace, dorsal view; B, mid-branchial spines, dorsal view; C, typical mid-branchial spine, lateral view; D, carapace, dorsal view; E, typical mid-branchial spine, right lateral view. Scale bars: A, 5 mm; B-E, $1 \mathrm{~mm}$.

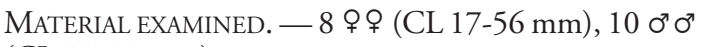
(CL 28-80 mm).

SPECIMENS Figured. - Drake Passage, 384-394 m, IX.1963, 1 \% CL 17.1 mm (USNM-154634). — South Georgia, 563-598 m, V.1975, 1 CL 55.6 mm (USNM231422).

\section{REMARKS}

The spines in the larger size classes of P. spinosissima (CL $>50 \mathrm{~mm}$ ) appear to be almost identical to P. multispina previously examined. Spines in adult specimens are stout, sharp and conical, flattened apically at an oblique (posterior facing) angle, and 

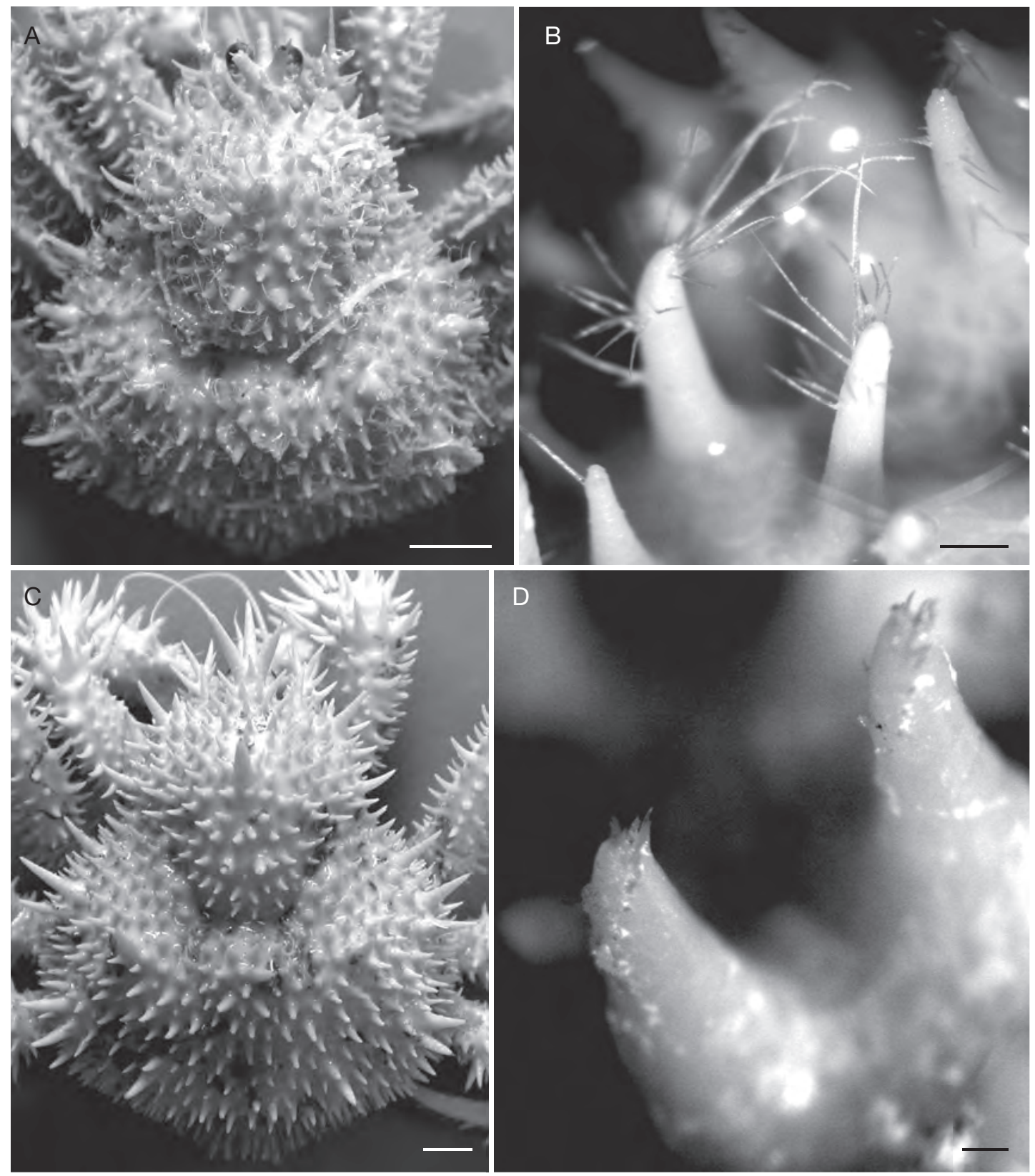

FIG. 8. - Paralomis spinosissima Birstein \& Vinogradov, 1972: A, B, \& CL 17.1 mm (USNM-154634), Drake's Passage, 384-394 m, IX.1963; C, D, \& CL 55.6 mm (USNM-231422), South Georgia, 563-598 m, V.1975; A, carapace, dorsal view; B, mid-branchial spines, dorsal view; C, carapace, dorsal view; D, branchial spines, dorso-lateral view. Scale bars: A, C, 5 mm; B, D, 1 mm.

with an apical circumference of short setae (Figs 7E; 8D). Juveniles (CL 7-30 mm) of P. spinosissima have long, sharp spines with long setae (Fig. 8B). Again, similar to P. multispina, one spine in the mid-gastric region on all sizes of specimen is prominent, and without setae or a blunt face posteriorly. 
Paralomis stella Macpherson, 1988 (Fig. 9)

Paralomis stella Macpherson, 1988c: 118, fig. 1, pl. 1A-C. TYPe LOCALity. - Réunion Island, 350-937 m.

Material eXamined. -6 우 (CL 39-49 mm), 7 o o o (CL 17-86 mm).

SpeCimens Figured. - Réunion Island, 350-750 m, 28.VIII.1982, 1 ơ CL 24.5 mm (MNHN Pg-4257). Réunion Islands, 450-937 m, 24.VIII.1982, 1 ơ CL $71.3 \mathrm{~mm}$ (MNHN Pg-4255).

\section{REMARKS}

Paralomis stella, from the south-eastern Indian Ocean, has a very similar adult spine morphotype, and a comparable ontogenetic progression to $P$. mendagnai. In both groups, the CL 10-25 mm size class have conical, spiniform tubercles, although in P. stella, none of the spines on the carapace are consistently enlarged in comparison to others on the same specimen. Adults larger than CL $30 \mathrm{~mm}$ have regular, rounded tubercles with pits (possibly minute setae) dispersed across the apex.

\section{DISCUSSION}

\section{ONTOGENETIC PATTERNS}

There appears to be no single function governing the ontogenetic change of carapace ornamentation across the genus Paralomis. In several of the groups (P. cubensis, Fig. 2; P. erinacea, Fig. 3; P. granulosa, Fig. 4; P. inca, Fig. 5; P. stella, Fig. 9), there is evidence for a progressive flattening of tubercles over subsequent moult stages. Additionally, in P. africana Macpherson, 1982, the ornamentation of the juvenile paratype (CL $15.7 \mathrm{~mm}$ ) is described as being "as in adults, but proportionally longer"(Macpherson 1982). This is not the case for all species - with the large spines of adult P. multispina (Fig. 7) developing contrary to this hypothesis from the pedunculated tubercles present in juveniles. It is clear, however, that significant and consistent changes do occur within species. If the ontogenetic progression for more species were recorded, it may also be possible to detect trends within lineages. The apparent convergence of form in spines of adult P. spinosis- sima and $P$. multispina suggests that we should be cautious about segregating lineages based on adult morphology alone.

\section{FUNCTIONALITY}

Little is known about the significance of the setae and tubercles for camouflage or protection in different habitats. Migrations during development are recorded for many lithodid species (Miquel et al. 1985; Abello \& Macpherson 1991; Stone et al. 1992; Lovrich \& Vinuesa 1995), and it seems reasonable to suggest the environmental pressures of changing habitats to explain a change in ornamentation. Thus, it is possible that changes in ornamentation are partially environmentally controlled. Juveniles are generally more densely ornamented than adults, and their spines tend to be proportionally longer. This may reflect the more vulnerable trophic position of the juveniles. Alternatively, the change in appearance may be a by-product of the as-yet-unknown mechanics of tubercle structure formation. The mechanism by which spines and tubercles are formed at each moult, and the genetic or epigenetic mechanism that controls their form should be investigated.

\section{APPLICATION TO OTHER LITHODID GENERA}

Paralomis has 61 extant species (Zaklan 2002; Hall \& Thatje 2009b), and as such is the most speciose genus of the Lithodidae. Species of this genus inhabit a wide variety of habitats, locations and depths, and their identification can pose a challenge for field-ecologists. Ontogenetic changes are documented for the eight out of 11 species of the deep-sea genus Neolithodes, as noted in many of their species descriptions (Benedict 1894; Barnard 1947; Macpherson 1988a). Spines in Neolithodes are long, thin and devoid of setae. The global, abyssal habitat of Neolithodes is more homogenous than that of Paralomis (Hall \& Thatje 2009a), but it has been observed that those species of Neolithodes inhabiting shallower water have a spinier carapace and legs than those in deeper waters in the same region (Smith 1882; Benedict 1894; Stebbing 1905; Barnard 1947). This may be evidence of a higher predatory pressure in shallow seas.

The genus Paralomis is monophyletic (Zaklan 2001; Hall \& Thatje 2009a) with respect to the 

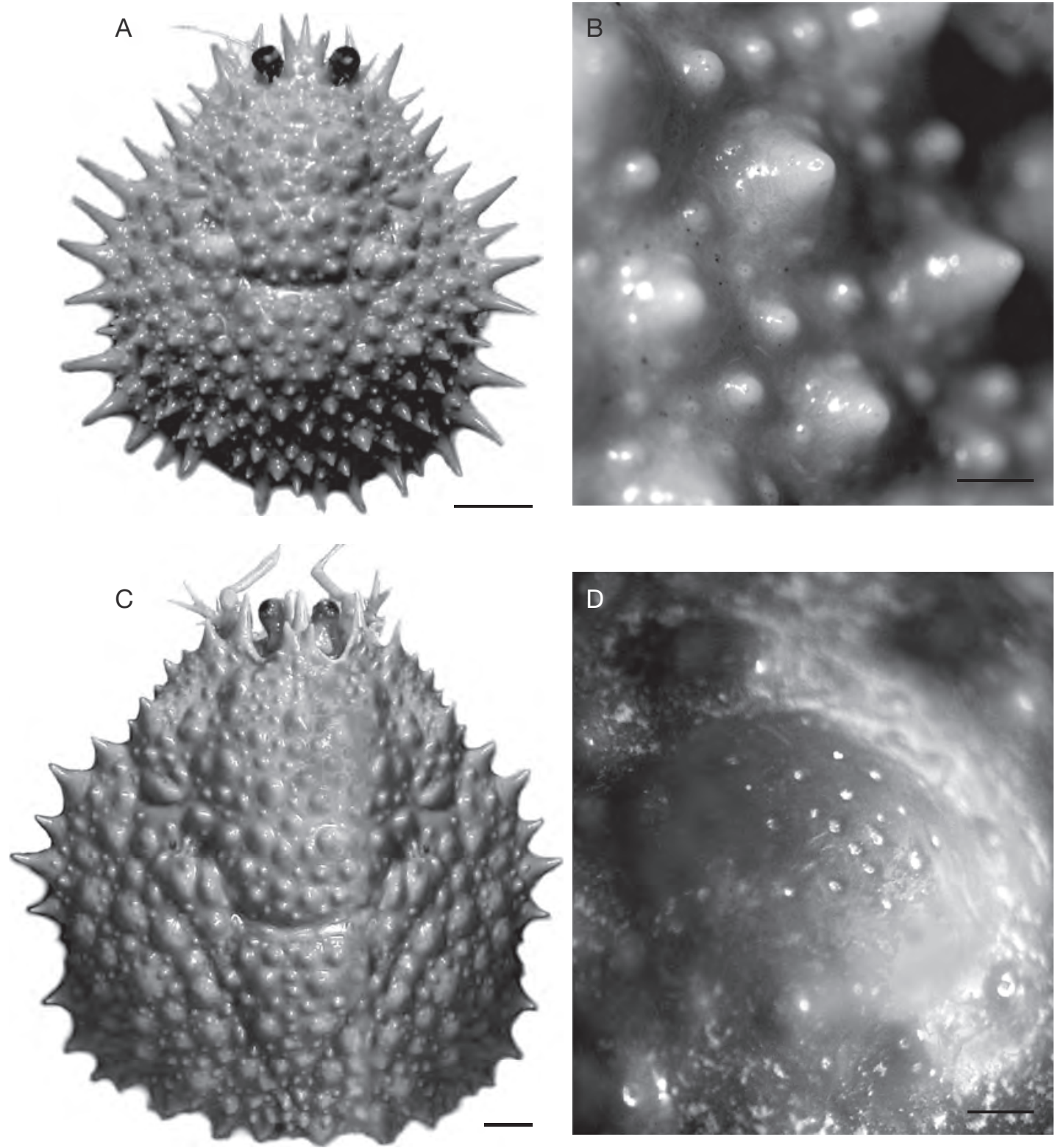

FIG. 9. - Paralomis stella Macpherson, 1988: A, B, ơ CL 24.5 mm (MNHN Pg-4257), Réunion Island, 350-750 m, 28.VIII.1982; C, D, holotype o $71.3 \mathrm{~mm}$ (MNHN Pg-4255); A, carapace, dorsal view; B, mid-branchial spines, left lateral view; C, carapace, dorsal view; D, mid-branchial tubercle, dorsal view. Scale bars: A, C, $5 \mathrm{~mm}$; B, $0.5 \mathrm{~mm}$; D, $1 \mathrm{~mm}$.

other major genera of the Lithodidae, although it is likely to include genus Glyptolithodes Faxon, 1895; the forms of carapace ornamentation documented here, are not found in any of the other lithodid groups. Genera Lithodes Latreille, 1806, and Neolithodes have long, thin spines with no setae; Hapalogastrine (soft bodied) genera, e.g., Hapalogaster Brandt, 1850, Dermaturus Brandt, 

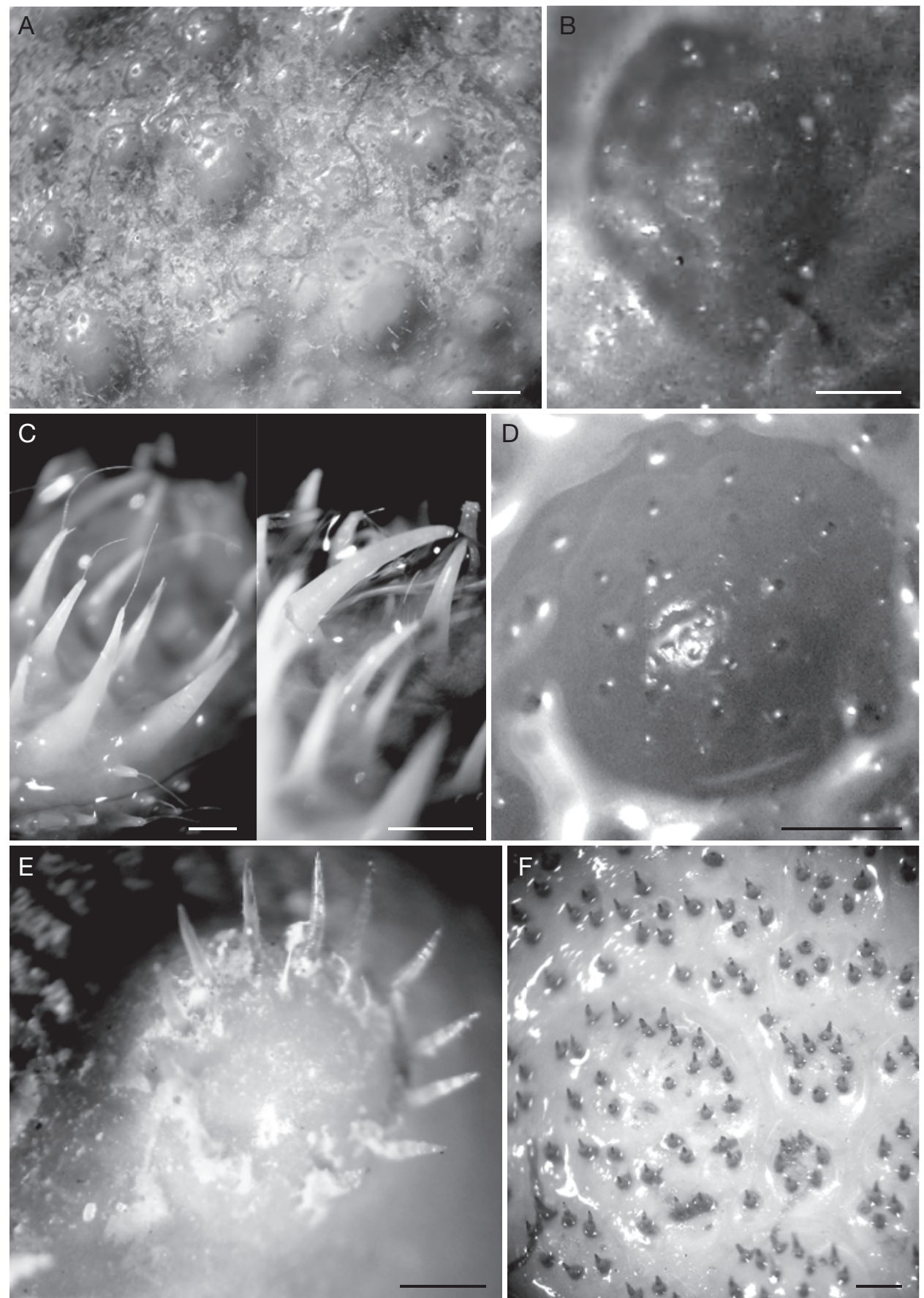

FIG. 10. - Northern and Eastern Atlantic Paralomis White, 1856 species: A, B, P. cristulata Macpherson, 1988, holotype $\$$ CL $55 \mathrm{~mm}$ (MNHN Pg-3427), Senegal, 650 m; C, P. bouvieri Hansen 1909, ơ CL 17.7 mm (USNM-231209); D, P. africana Macpherson, 1982, ơ CL 68.4 mm (USNM-213153); E, P. grossmani Macpherson, 1988, holotype + CL 93.4 mm (USNM-228832); F, P. pectinata Macpherson, 1988, holotype \& CL 96.4 mm (USNM-233599); A, B, D-F, mid-branchial tubercles, dorsal view; C, carapace spines, lateral view. Scale bars: $1 \mathrm{~mm}$ 

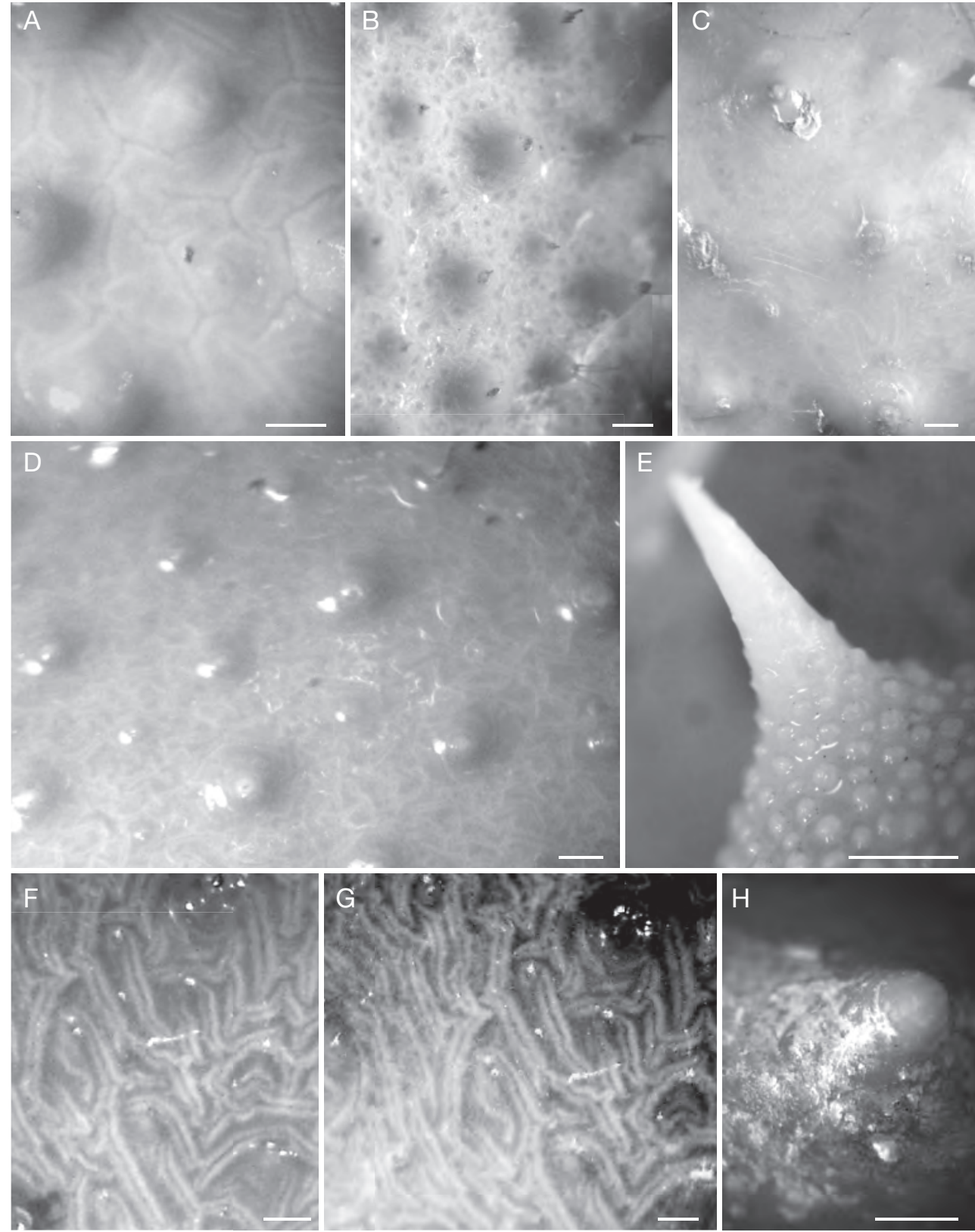

FIG. 11. - Southern Ocean Paralomis White, 1856 species: A, B, P. aculeata Henderson, 1888, holotype ơ CL 41 mm (BMNH 88.33 ), Prince Edward Islands; C, P. elongata Spiridonov, Türkay, Arntz \& Thatje, 2006, \& CL $65 \mathrm{~mm}$ (collection S. Thatje, NOCS), Bouvet Island; D, P. anamerae Macpherson, 1988, o CL 72 mm, MD24 Crozet Island, 655-700 m, IX.1980; E, F, P. formosa Henderson, 1888; E, paratype ơ CL $16.4 \mathrm{~mm}$ (BMNH 88.33), Rio Plata; F, ơ CL $72.6 \mathrm{~mm}$ (collection S. Thatje, NOCS), South Georgia groundfish survey; G, H, P. birsteini Macpherson, 1988, holotype o CL $54.7 \mathrm{~mm}$ (USNM-228830); A, mid-branchial region, dorsal view; B, antero-lateral carapace, dorsal view; C, mid-branchial region, depicting significant intermoult wear on the tubercles, dorsal view; D, mid-branchial region, dorsal view; $\mathbf{E}$, base of a lateral spine, showing secondary tubercles in juvenile specimen, dorsal view; $\mathbf{F}$, mid-branchial region, not showing main spines, which are up to $10 \mathrm{~mm}$ in length, dorsal view; $\mathbf{G}$, mid branchial region, dorsal view; $\mathbf{H}$, mid-branchial tubercle, lateral view. Scale bars: A, C, E, G, H, 1 mm; B, 3 mm; D, F, 2 mm. 

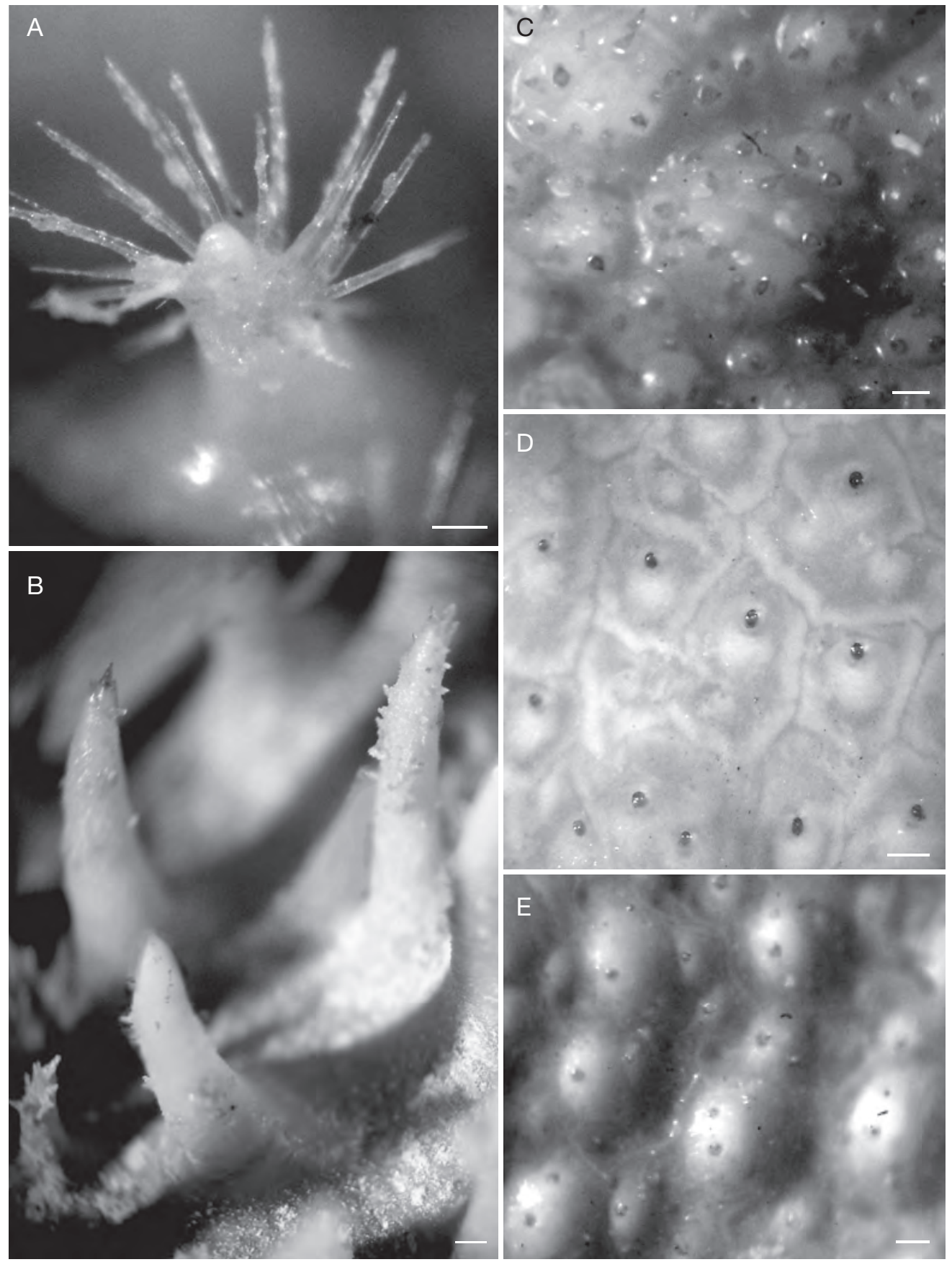

FIG. 12. - South America (west coast) Paralomis White, 1856 species: A, P. aspera Faxon, 1893, ơ CL 53 mm (BMNH), Coquimbo, $560 \mathrm{~m}$, Vl.1971; B, P. phrixa, Macpherson, 1992, holotype 9 CL 64.6 mm (USNM-259380); C, P. arae Macpherson, 2001, holotype ơ CL 74.5 mm (MNHN Pg 5945); D, P. otsuae Wilson, 1990, ๆ 73.4 mm (USNM-259219); E, Glyptolithodes cristatipes Faxon, 1893, ᄋ CL 71.2 mm (USNM-259216); A, B, mid-branchial spines, postero-lateral view; C-E, mid-branchial region, dorsal view. Scale bars: $1 \mathrm{~mm}$. 

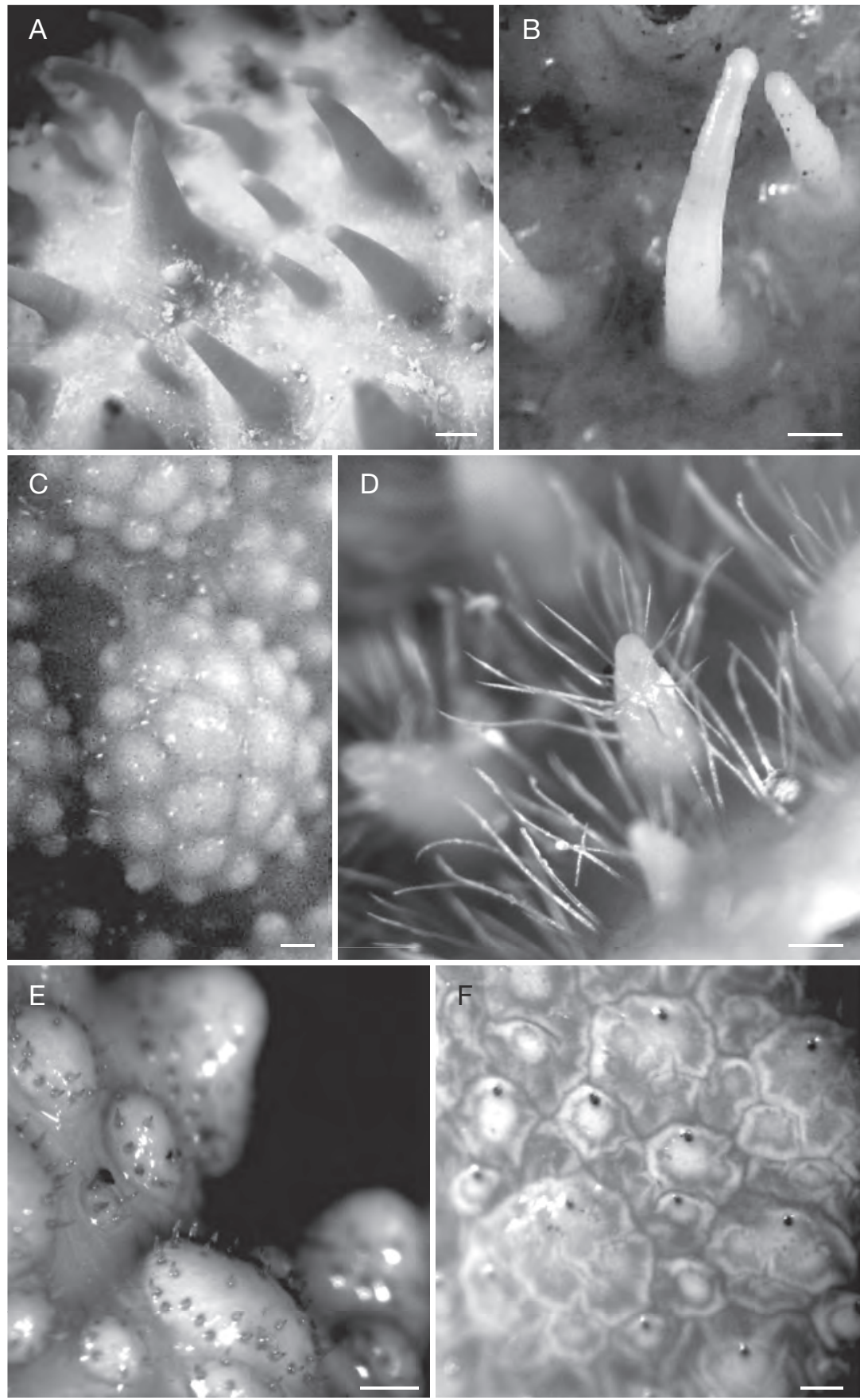

FIG. 13. - Japan and North Pacific species of Paralomis White, 1856: A, B, P. histrix De Haan, 1844; A, CL 63.2 mm (BMNH 1985.140); B, ơ CL 34.9 mm (MNHN Pg 2212); C, P. japonica Balss, 1911, ơ CL 46.7 mm (MNHN); D, P. makarovi Hall \& Thatje, 2009, ơ CL 23 mm (USNM-1122582); E, P. cristata Takeda \& Ohta, 1979, o 76.4 mm (USNM-229721); F, P. verrilli (Benedict, 1894), holotype ơ CL 78 mm (USNM-18537); A, B, D, mid-branchial spines, lateral view; C, E, F, mid-branchial tubercles, dorsal view. Scale bars: A, $3 \mathrm{~mm} ; \mathrm{B}, \mathrm{E}, 2 \mathrm{~mm} ; \mathrm{C}, \mathrm{D}, \mathrm{F}, 1 \mathrm{~mm}$. 

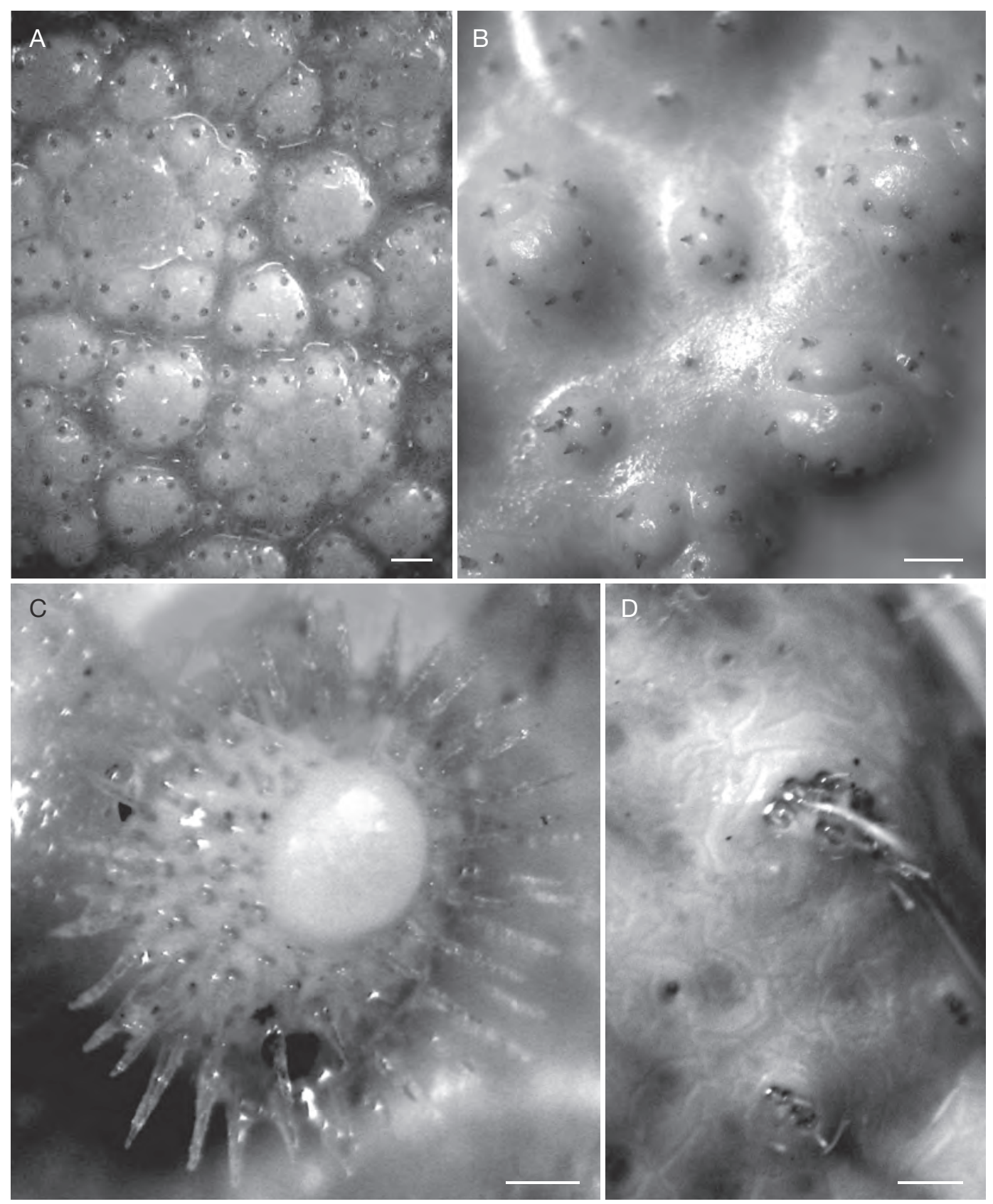

FIG. 14. - Central Pacific Paralomis White, 1856 species: A, P. seagranti Eldredge, 1976, ơ CL 74.7 mm (MNHN Pg-4265); B, P. dawsoni Macpherson, 2001, ㅇ CL 57.3 mm (MNHN Pg-4279); C, P. haigae Eldredge, 1976, ơ CL 49.9 mm (MNHN Pg-4276); D, P. hirtella de Saint-Laurent \& Macpherson, 1997, ơ CL 47 mm (MNHN Pg-4662); A-D mid-branchial tubercles, dorsal view. Scale bars: 1 mm. 
1850, Oedignathus Benedict, 1894, have features, described as "scales", which have setae on their anterior edges (Zaklan 2001).

\section{TERMinOLOGY}

It is with particular difficulty that the tubercular structures of the Lithodidae are described. Aligning the descriptions in original works with pictures taken of adults (type specimens where possible: Appendix 1), highlights deficiencies in the current semantics (for example, where $P$. aculeata in Spiridonov et al. (2006) [Fig. 11A, B] is described in the same way as P. pectinata in Macpherson (1988a) [Fig. 10F]). Ornamentational structures with different basic forms are not adequately differentiated in descriptions. While it might be possible to create a complex universal classification of carapace ornamentation for the Lithodidae, this would involve conjecture on the homology and the biological processes involved in tubercle development. Here (Fig. 1), we describe a method of standardising the terminology for carapace ornamentation to make the process of defining species more objective. This is complicated by the fact that tubercles may be able to change between these forms over successive moults and we strongly encourage the use of diagrams or photographs (which are lacking from most of the original descriptions) to illustrate the different forms of tubercles found in this genus.

\section{SUMMARY}

This work highlights the need for the entire growth spectrum to be taken into account when identifying species. The fact that many described lithodid species are represented by only a few specimens underlines the importance of this comparative approach, in which general patterns for the genus are sought. We emphasize the need for drawings or photographs of surface ornamentation to accompany descriptive works, and also highlight the need for the description of variations in morphology when juvenile specimens are found.

\section{Acknowledgements}

We would like to thank staff at the USNM, especially Rafael Lemaitre and Karen Reed; Régis Cleva
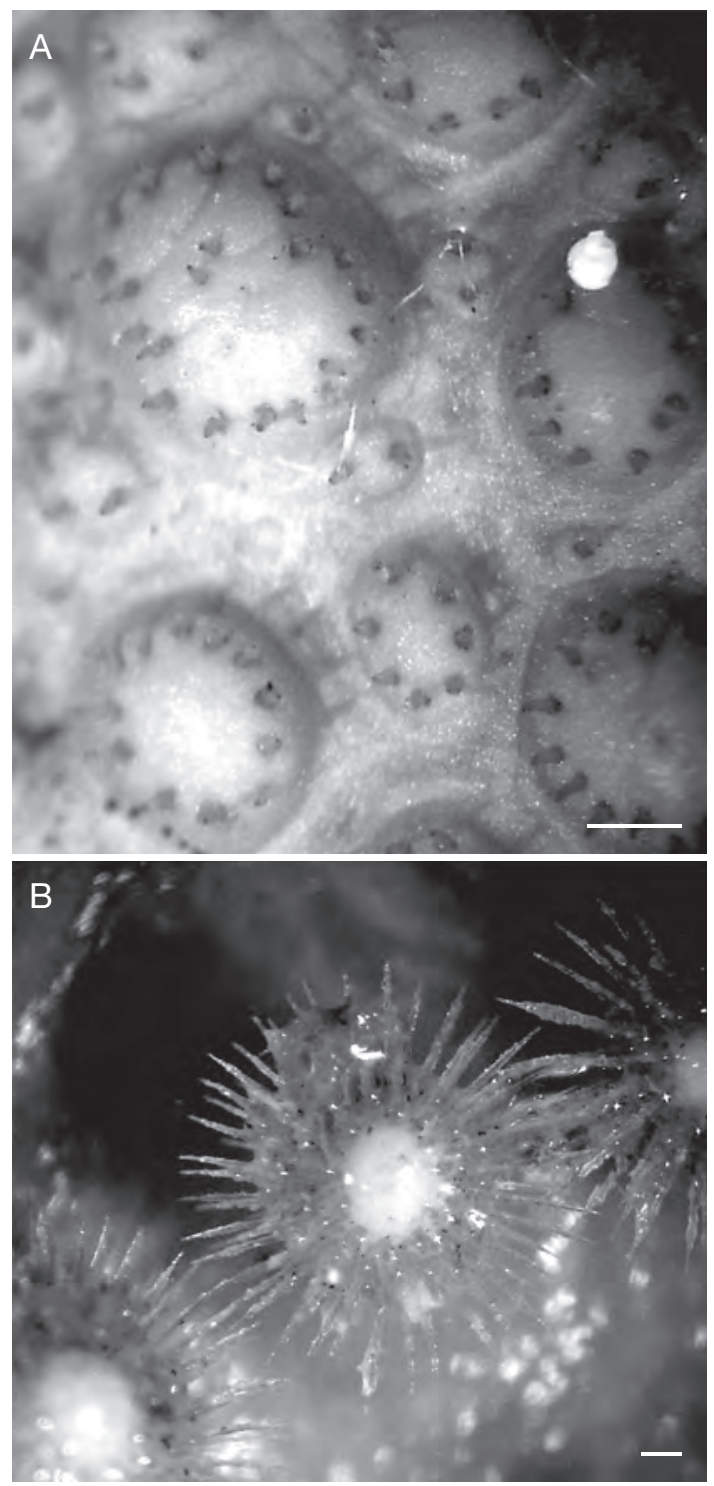

FIG. 15. - Indian Ocean species of Paralomis White, 1856: A, P. ceres, Macpherson, 1989, holotype ơ CL $58.1 \mathrm{~mm}$ (BMNH 1989.926); B, P. ochthodes Macpherson, 1988, holotype ơ CL 71.6 mm (USNM-228831); A, B, mid-branchial tubercles, dorsal view. Scale bars: $1 \mathrm{~mm}$.

(MNHN); Paul Clark (BMNH); Enrique Macpherson (Centro de Estudios Avanzados de Blanes); Michael Türkay (Senckenberg Museum, Frankfurt); and Anna Ramos and her group (Instituto Español de Oceanografía, Vigo). This study would not have 
been possible without such a wide range of material made available by these institutions. This work was supported by the Marine Biodiversity and Ecosystem Functioning Network of Excellence MarBEF (contract no. GOCE-CT-2003-505446) of the FP6, and through a NERC PhD studentship to $\mathrm{SH}$.

\section{REFERENCES}

ABELlo P. \& MACPHERSON E. 1991. — Distribution patterns and migration of Lithodes ferox Filhol (Anomura: Lithodidae) off Namibia. Journal of Crustacean Biology 11 (2): 261-268.

Alcock A. \& Anderson A. R. S. 1899. - Natural history notes from $\mathrm{H}$. M. royal Indian marine survey ship Investigator. Commander T. H. Hemming, R.N. commanding series III, No. 2. An account of the deep-sea Crustacea dredged during the surveying season of 1897-1898. Annals of the Magazine of Natural History, series 7, 3: 1-27.

Andrade H. 1980. - Nueva especie de Paralomis en aguas de Chile: Paralomis chilensis n. sp. Boletin del museo nacional de historia natural, Santiago, Chile 37: 269-273.

BARNARD K. H. 1947. - Descriptions of new species of South African decapod Crustacea, with notes on synonomy and new records. Annals and Magazine of Natural History, Series 11, 13: 361-392.

BENEDICT J. E. 1894. - Scientific results of explorations by the U.S. Fish Commission steamer Albatross. No. XXXI. Descriptions of new genera and species of crabs of the family Lithodidae, with notes on the young of Lithodes camtschaticus and Lithodes brevipes. Proceedings of the United States National Museum 17: 479-488.

BirSteIn Y. A. \& VinOgradov L. G. 1972. — Craboids (Decapoda: Anomura: Lithodidae) of the Atlantic sector of the Antarctic, South America, and South Africa. Zoologichesky Zhurnal 51: 351-363.

BOUVIER E. L. 1895. - Recherches sur les affinités des Lithodes et Lomis avec les Pagurides. Annales des Sciences naturelles, Zoologie et Paléontologie (7) 18: 157-213.

BOUVIER E. L. 1896. — Sur la classification des Lithodines et sur leur distribution dans les océans. Annales des Sciences naturelles, Zoologie et Paléontologie (8) 1: $1-46$.

CHACE F. A. 1939. - Reports on the scientific results of the first Atlantis expedition to the West Indies, under the joint auspices of the University of Havana and Harvard. Preliminary descriptions of one new genus and seventeen new species of decapod and stomatopod crustaceans. Memórias de la Sociedad Cubana de Historica Natural 13: 31-54.

Cunningham R. O. 1871. - Notes on the natural history of the Strait of Magellan and west coast of Patagonia made during the voyage of HMS Nassau in the years 1866-1869. Transactions of the Linnean Society of London, Zoology 27: 465-502.

DANA J. D. 1852. — Conspectus Crustaceorum: Crustacea Paguridea, Megalopidea, and Macroura. Proceedings of the Academy of Natural Sciences of Philadelphia 6: 6-28.

DANA J. D. 1855. - Geographical distribution of Crustacea. American Journal of Science 17: 314-326; 19: 6-15; 20: 168-178; 349-361.

DaWson E. W. \& YaldWYN J. C. 1971. — Diagnosis of a new species of Paralomis (Crustacea: Anomura: Lithodidae) from New Zealand. Records of the Dominion Museum 7: 51-54.

Del Solar E. M. 1972. - Addenda al catalogo de crustaceos del Peru. Informe Instituto del Mar del Peru 38: 1-21.

Eldredge L. G. 1976. — Two new species of lithodid crabs from Guam. Micronesica 12: 309-315.

FAXON W. 1895. —XV The stalk-eyed Crustacea. Reports of the exploration off the west coast of Mexico, Central and South America, and the Galapagos Islands by the U.S. Fish Commission steamer Albatross during 1891. Memoirs of the Museum of Comparative Zoology, Harvard College 18: 42-52.

HAIG J. 1974. - Observations on the lithodid crabs of Peru, with description of two new species. Bulletin of the Southern California Academy of Science 73: 152-164.

Hall S. \& Thatje S. 2009a. - Global bottlenecks in the distribution of marine Crustacea: temperature constraints in the family Lithodidae. Journal of Biogeography 36 (11): 2125-2135.

Hall S. \& Thatje S. 2009b. - Four new species of the family Lithodidae (Decapoda: Anomura) from collections of the National Museum of Natural History, Smithsonian Institution. Zootaxa 2302: 31-47.

IKeDA H. 1998. - The Deep-Sea Crabs of Sagami Bay. Hayama Siosai Museum, Kanagawa, Japan, 180 p.

INGLE R. W. 1981. - The larval and post larval development of the edible crab Cancer pagurus Linnaeus (Decapoda: Brachyura). Bulletin of the British Museum (Natural History) (Zoology), London 40 (5): 211236.

InGLe R. W. \& GARRod C. 1987. - Ornamentation changes associated with growth of Falkland Island populations of Paralomis granulosa (Jacquinot, 1842-1847) (Decapoda: Lithodidae). Crustaceana 52: 220-224.

JaQUinot H. 1847. - Crustacea, in JaQUinOT H. \& LuCAS H. (eds), Voyage au Pôle sud et dans l'Océanie sur les corvettes L'Astrolabe et La Zélée, exécutépendant les années 1837-1840 sous le commandement de M.J. Dumont d'Urville, Capitaine de vaisseau, publié par ordre du Gouvernement et sous la direction supérieure 
de M. Jaquinot \& c. Zoologie. III. Gide et Baudry, Paris, $107 \mathrm{p}$.

JaQuinot H. 1853. - Crustacea, in JaQUinOt H. \& LuCAS H. (eds), Voyage au Pôle sud et dans l'Océanie sur les corvettes L'Astrolabe et La Zélée, exécuté pendant les années 1837-1840 sous le commandement de M. J. Dumont d'Urville, Capitaine de vaisseau, publié par ordre du Gouvernement et sous la direction supérieure de M. Jaquinot \& c. Zoologie. III. Gide et Baudry, Paris, $107 \mathrm{p}$.

Kensley B. 1981. - The South African Museum's Meiring Naude cruises. Pt 12: Crustacea Decapoda of the 1977, 1978, 1979 cruises (Description of Paralomis roelveldae). Annals of the South African Museum 83: 49-78.

LOVRICH G. A. \& VinUesa J. H. 1993. - Reproductive biology of the false southern king crab (Paralomis granulosa, Lithodidae) in the Beagle Channel, Argentina. Fishery Bulletin 91 (4): 664-675.

LOVRICH G. A. \& VinUesA J. H. 1995. - Growth of immature false southern king crab, Paralomis granulosa (Anomura: Lithodidae) in the Beagle Channel, Argentina. Scientia Marina 59 (1): 87-94.

MaCPHERSON E. 1982. - A new species of Paralomis (Decapoda: Anomura) from the south eastern Atlantic. Crustaceana 43 (2): 142-146.

MACPHERSON E. 1988a. - Revision of the family Lithodidae Samouelle, 1819 (Crustacea: Decapoda: Anomura) in the Atlantic Ocean. Monografias de Zoologia Marina 2: 9-153.

MACPHERSON E. 1988b. - Three new species of Paralomis (Crustacea, Decapoda, Anomura, Lithodidae) from the Pacific and Antarctic oceans. Zoologica Scripta 17 (1): 69-75.

MACPHERSON E. 1988c. — Lithodid crabs (Crustacea, Decapoda, Lithodidae) from Madagascar and La Réunion (SW Indian Ocean) with descriptions of two new species. Bulletin du Muséum national d'Histoire naturelle, 4e sér., section A, 10 (1): 117-133.

MACPHERSON E. 1989. - A new species of the genus Paralomis from the Indian Ocean. Scientia Marina 53: 117-120.

MacPherson E. 1990. - Crustacea Decapoda: on some species of Lithodidae from the western Pacific, in Crosnier A. (ed.), Résultats des campagnes MUSORSTOM, volume 6. Mémoires du Muséum national d'Histoire naturelle 145: 217-226.

MACPHERSON E. 1992. - Paralomis phrixa (Decapoda: Anomura: Lithodidae), a new species from northern Peru, and a key to the eastern Pacific species of the genus. Crustaceana 63: 313-317.

MACPHERSON E. 2001. - New species and new records of lithodid crabs (Crustacea, Decapoda) from the south western and central Pacific. Zoosystema 23 (4): 797-805.

MACPHERSON E. 2003. — Some lithodid crabs (Crustacea:
Decapoda: Lithodidae) from the Solomon Islands (SW Pacific Ocean), with the description of a new species. Scientia Marina 67 (4): 413-418.

MACPHERSON E. 2004. - A new species and new records of lithodid crabs (Crustacea: Decapoda: Lithodidae) from the Crozet and Kerguelen Islands area (Subantarctica). Polar Biology 27 (7): 418-422.

MACPHERSON E. \& CHAN T. Y. 2008. - Some lithodid crabs (Crustacea: Decapoda: Lithodidae) from Taiwan and adjacent waters, with the description of one new species from Guam. Zootaxa 1924: 43-52.

McCaughran D. A. \& Powell G. C. 1977. — Growth model for Alaska king crab Paralithodes camtschatica. Journal of the Fisheries Research Board Canada 34: 989-995.

MAKAROV V. V. 1938. - [Crustacea], in [Fauna of U.S.S.R.] vol. 10, no. 3: 1-283 (in Russian, English translation published in 1962 by Israel Program for Scientific Translations, Jerusalem).

Miquel J. C., Arnaud P. M. \& Dochi T. 1985. Population structure and migration of the stone crab Lithodes murrayi in the Crozet Islands, sub-Antarctic Indian Ocean. Marine Biology 89 (3): 263-269.

Rathbun M. J. 1904. - Decapod crustaceans of the northwest coast of North America. Harriman Alaska Expedition Series 10, 210 p.

SAKAI T. 1971. - Illustrations of 15 species of crabs of the family Lithodidae, two of which are new to science. Researches on Crustacea 4-5: 1-491.

SAKAI T. 1980. - New species of crabs of the families Lithodidae and Calappidae. Researches on Crustacea 10: 1-11.

Saint Laurent M. De \& Macpherson E. 1997. Paralomis White, 1856, a new species from south west Pacific hydrothermal vents (Crustacea: Decapoda) Zoosystema 19 (4): 721-727.

SCHMiDTT W. L. 1921. - The marine decapod Crustacea of California. University of California Publications in Zoology 23: 1-470.

SMitH S. I. 1882. - Report on the Crustacea. Part I. Decapoda. Reports on the results of dredging, under the supervision of Alexander Agassiz, on the east coast of the United States, during the summer of 1880, by the U.S. coast Survey Steamer "Blake". Bulletin of the Museum of Comparative Zoology, Harvard College. 10: 1-108.

Spiridonov V., TÜrkay M., Arntz W. \& Thatje S. 2006. - A new species of the genus Paralomis from the Spiess seamount near Bouvet Island (Southern Ocean), with notes on habitat and ecology. Polar Biology 29: 137-146.

Stebbing T. R. R. 1905. - South African Crustacea. Part 3. Marine Investigations in South Africa IV: 21-123, 10 pls.

StONE R. P., OCLAir C. E. \& SHIRLEY T. 1992. — Seasonal migration and distribution of female red king crabs 
in a south east Alaskan estuary. Journal of Crustacean Biology 12 (4): 546-560.

TAKEDA M. 1974. - On three species of the Lithodidae from the central Pacific. Bulletin of the National Museum of Nature and Science Series A - Zoology 17: 200-212.

TaKeda M. \& Ohta S. 1979. - A new species of the Lithodidae from Suruga Bay, central Japan. Bulletin of the National Museum of Nature and Science Series A - Zoology 5: 195-200.

TAKeda M. 1980. - A new species of Paralomis from the East China Sea. Annotated Zoology, Japan 53: 42-45.

Takeda M. \& Bussarawit S. 2007. - A new species of the genus Paralomis White, 1856 (Crustacea: Decapoda: Anomura: Lithodidae) from the Andaman Sea. Bulletin of the National Museum of Nature and Science Series A - Zoology 33 (2): 51-59.

Thatje S., Hall S., Held C., Hauton C. \& Tyler P. 2008. - Encounter of Paralomis birsteini on the continental slope of Antarctica, sampled by ROV.
Polar Biology 31 (9): 1143-1148.

WhiTe A. 1847b. - Descriptions of new or little-known Crustacea in the collection of the British Museum. Proceedings of the Zoological Society of London 15: 118-126.

White A. 1856. - Some remarks on Crustacea of the genus Lithodes, with a brief description of a species apparently hitherto unrecorded. Proceedings of the Zoological Society of London 24: 132-135.

WILSON R. 1990. - Paralomis otsuae, a new species of Decapoda Anomura from deep water off the Chilean coast. Crustaceana 58: 130-135.

ZAKLAN S. D. 2001. - Evolutionary History and Phylogeny of the Family Lithodidae. PhD Thesis, University of Alberta, Edmonton, 275 p.

ZAKLAN S. D. 2002. - Review of the family Lithodidae (Crustacea: Anomura: Paguroidea): distribution, biology, and fisheries, in MACINTOSH R. A. (ed.), Crabs in Cold Water Regions: Biology, Management, and Economics. Alaska Sea Grant College Program AK-SG-02-01, Anchorage: 751-845. 


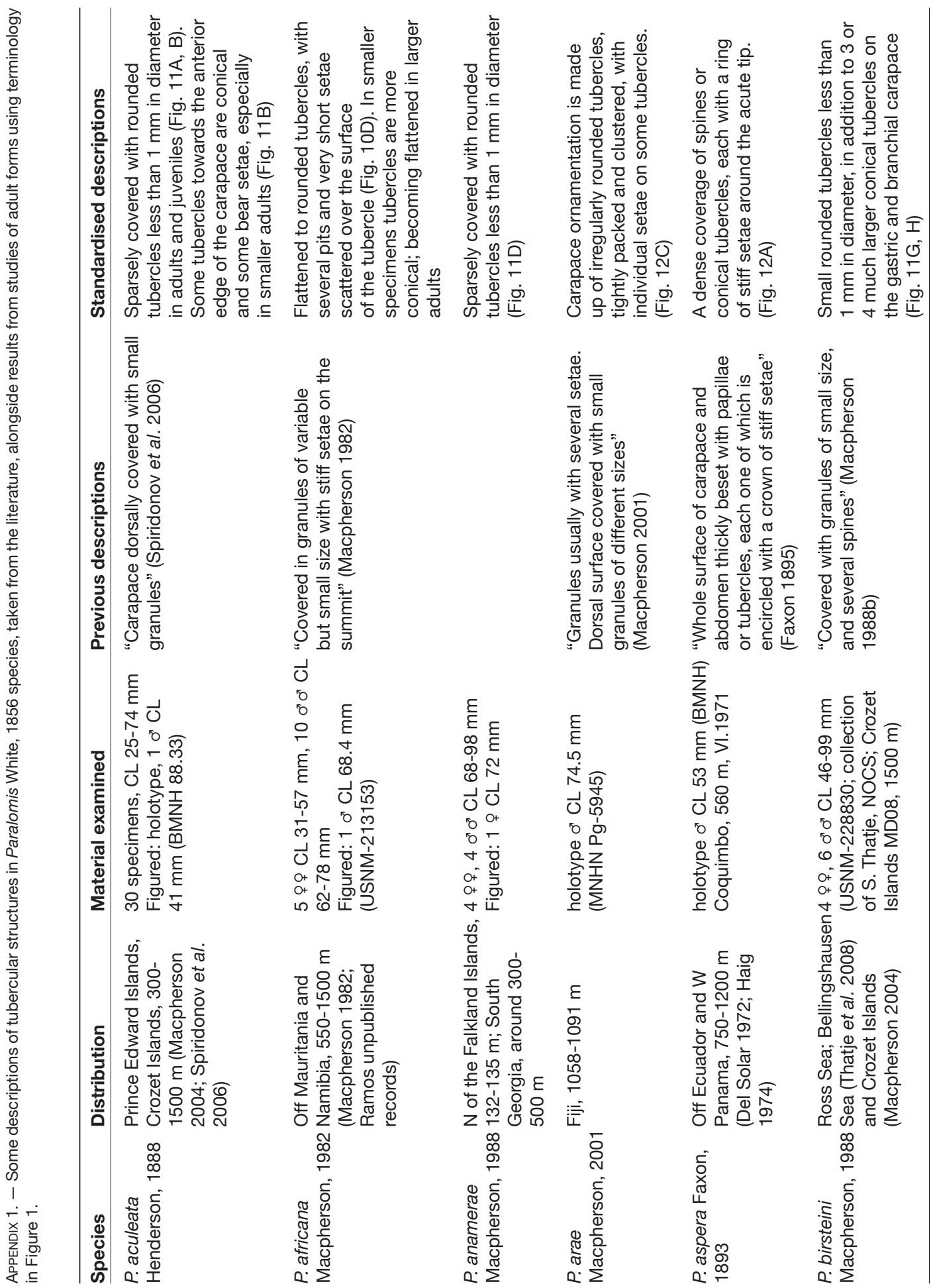




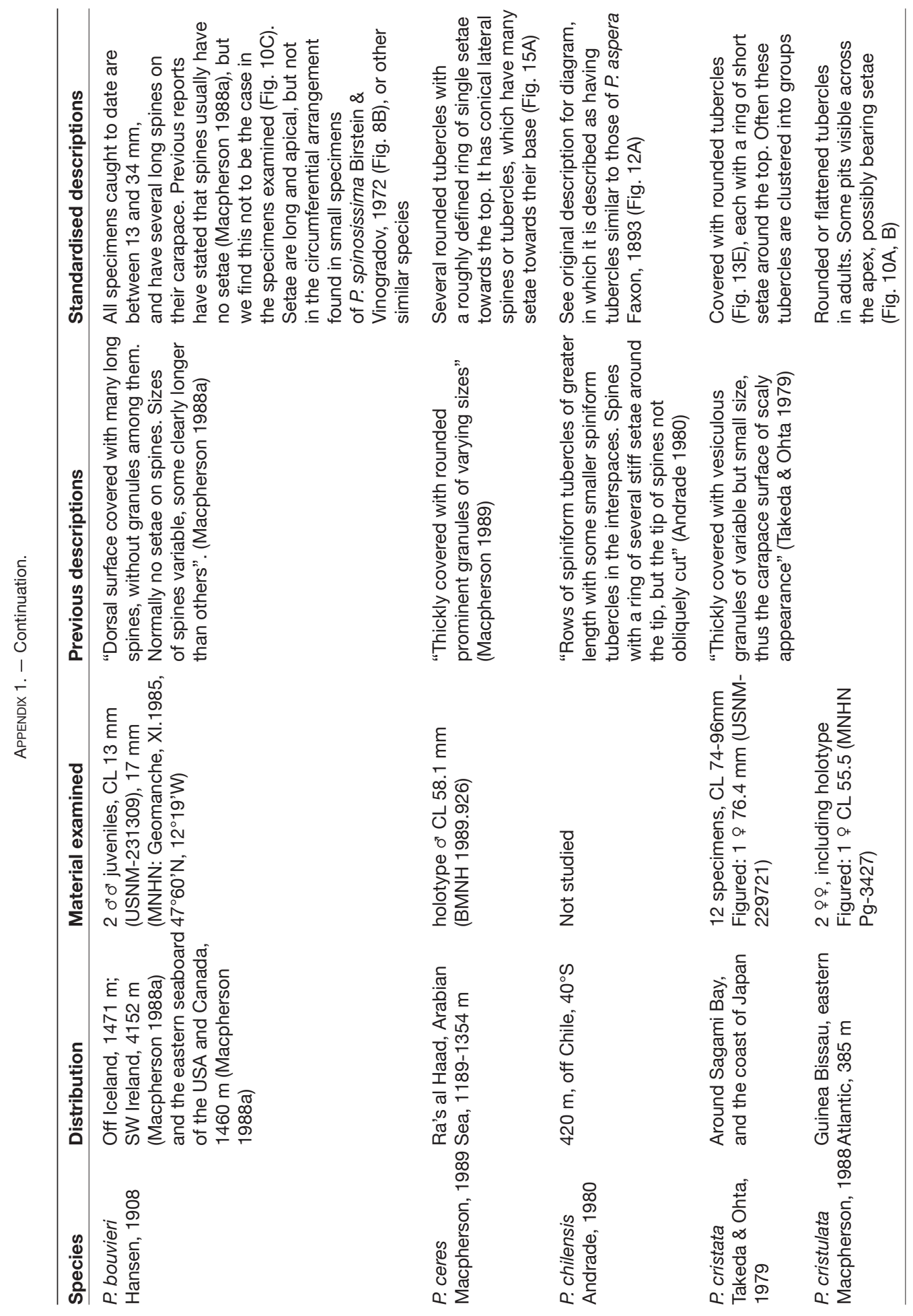




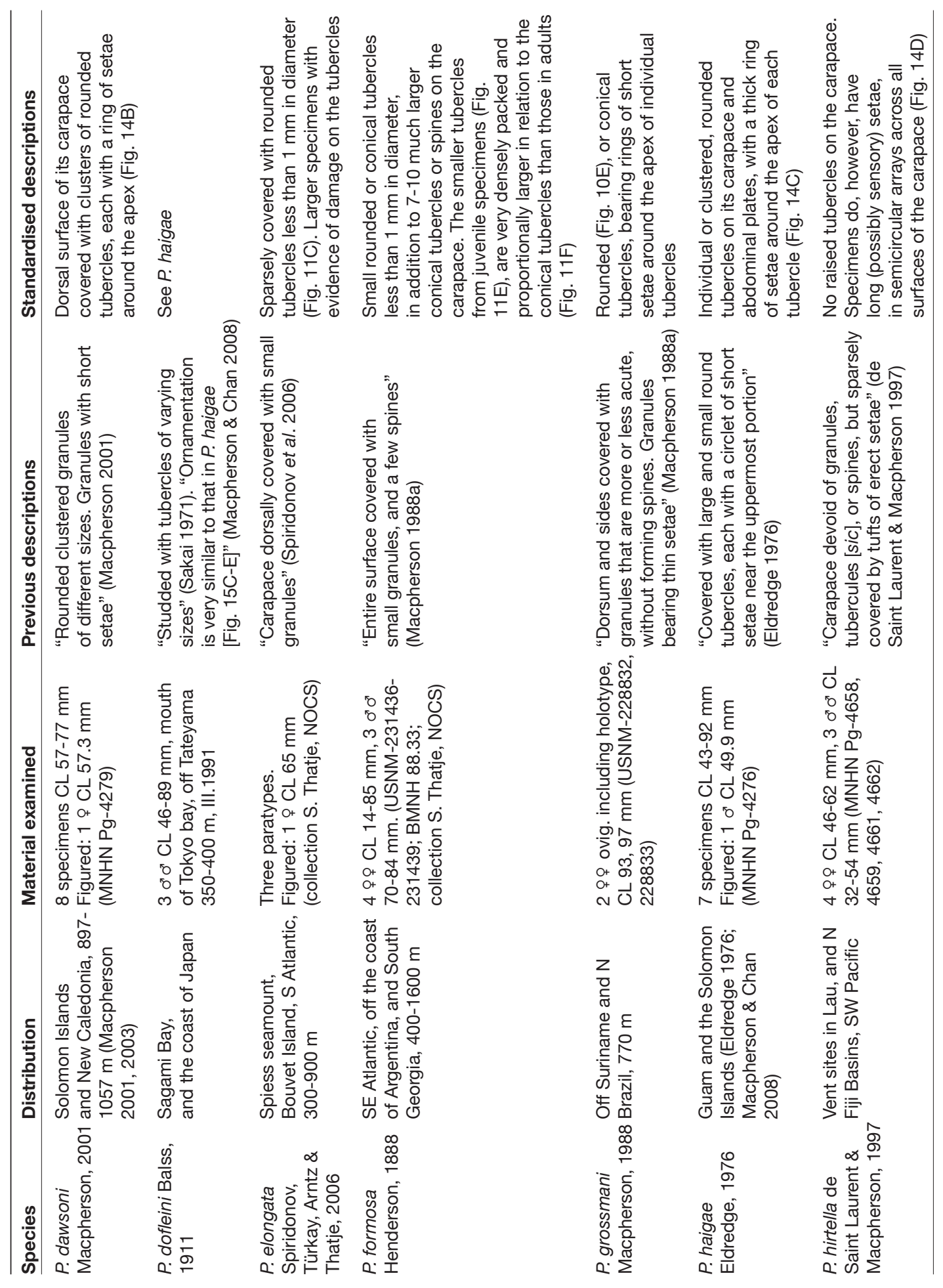




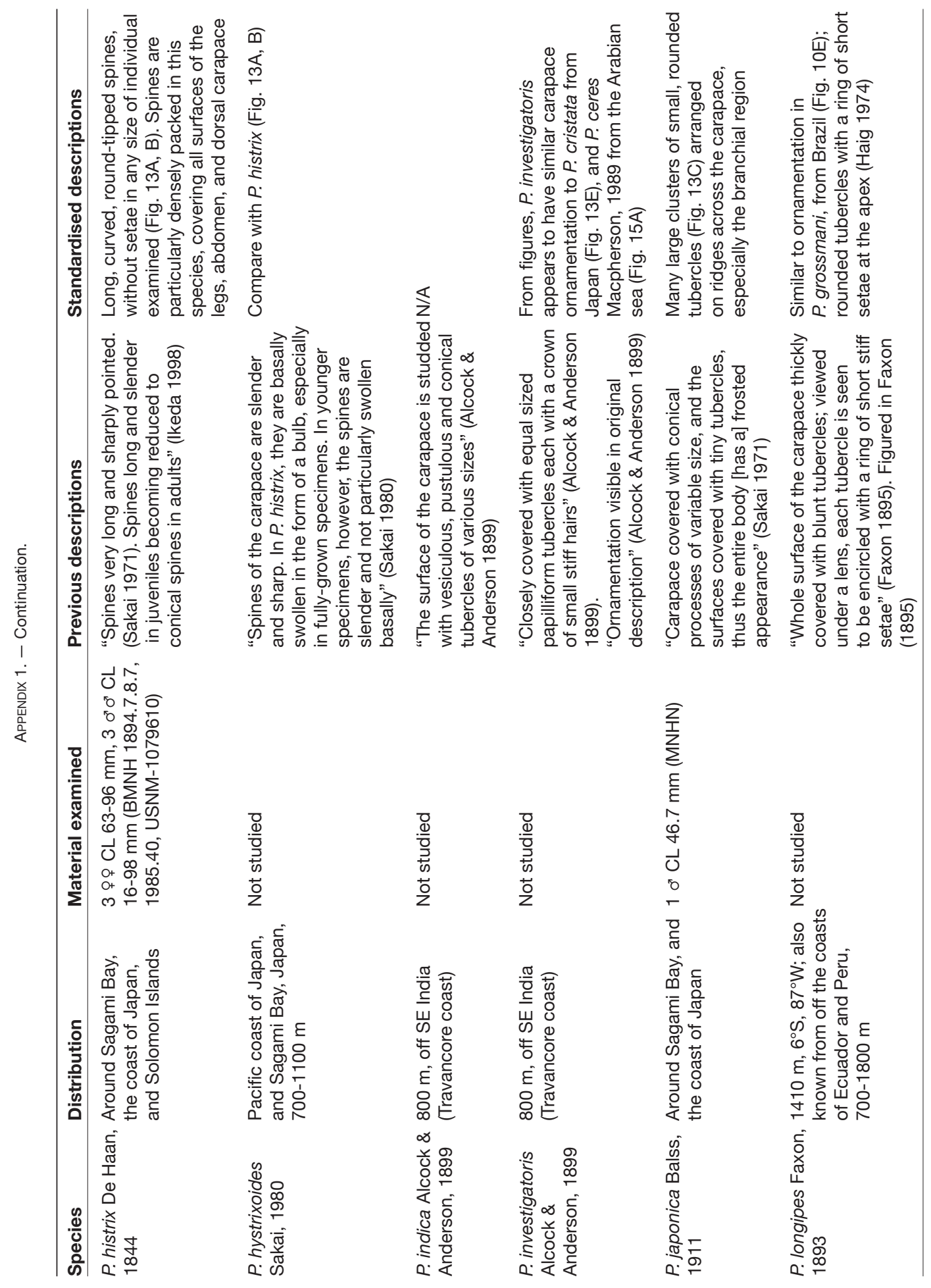




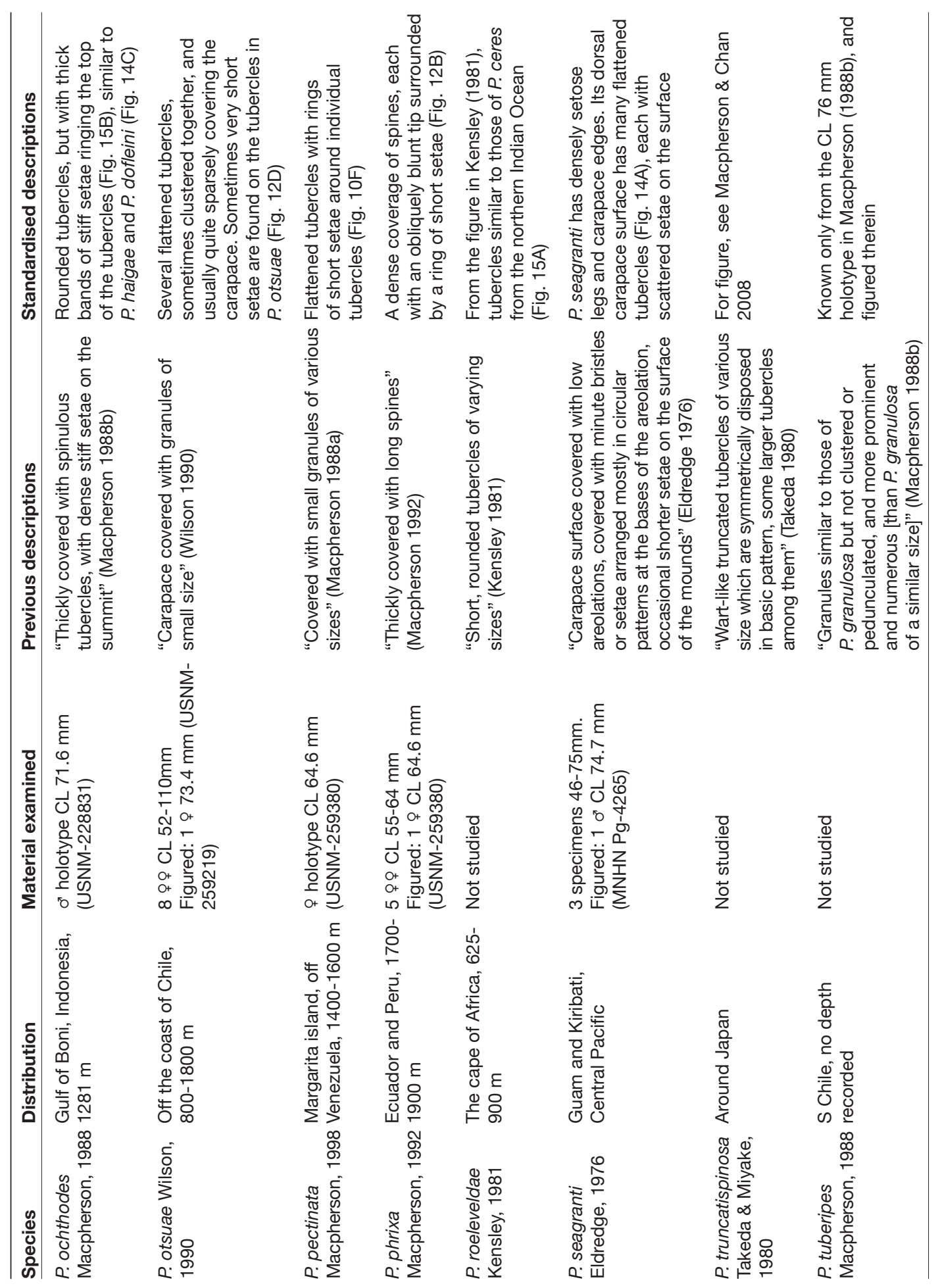




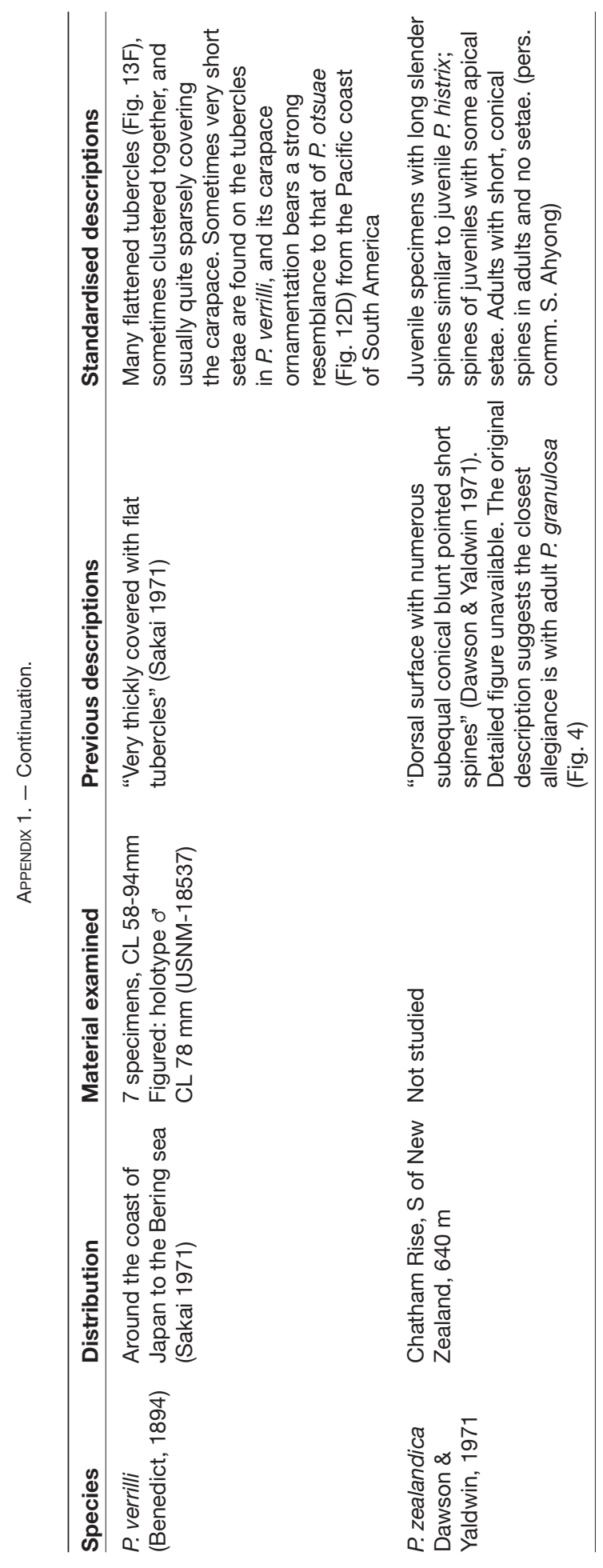

